\title{
Financial Reporting Quality of Chinese Reverse Merger Firms: The Reverse Merger Effect or the Weak Country Effect?
}

\author{
Kun-Chih Chen \\ National Taiwan University \\ Qiang Cheng \\ Singapore Management University \\ Ying Chou Lin \\ Southeastern Oklahoma State University \\ Yu-Chen Lin \\ National Cheng-Kung University \\ Xing Xiao \\ Tsinghua University
}

\begin{abstract}
In this paper, we examine why Chinese reverse merger (RM) firms have lower financial reporting quality than U.S. IPO firms. We find that the financial reporting quality of U.S. RM firms is similar to that of matched U.S. IPO firms, but Chinese RM firms exhibit lower financial reporting quality than Chinese ADR firms. We also find that Chinese RM firms exhibit lower financial reporting quality than U.S. RM firms. These results indicate that the use of the RM process is associated with poor financial reporting quality only in firms from China, where legal enforcement and investor protection are weak. In addition, we find that compared with Chinese ADR firms, Chinese RM firms have weaker bonding incentives (as measured by CEO turnover-performance sensitivity) and poorer corporate governance. These factors, in turn, contribute to the lower financial reporting quality of Chinese RM firms. Overall, our results suggest that the less scrutinized RM process allows the Chinese firms with weak bonding incentives and poor governance to gain access to U.S. capital markets, resulting in poor financial reporting quality.
\end{abstract}

Keywords: reverse mergers; Chinese firms; financial reporting quality; bonding hypothesis; cross-listings.

JEL Classifications: G15; G24; G34; G38.

\section{INTRODUCTION}

I

$\mathrm{n}$ this paper, we examine why Chinese reverse merger (RM) firms listed in the U.S. have lower financial reporting quality than U.S. initial public offering (IPO) firms. This examination is motivated by the recent popularity of Chinese RM firms and by the accounting problems associated with these firms during the past few years. In an RM deal, a U.S. public shell

We thank Chih-Ying Chen, Xia Chen, Ole-Kristian Hope, Siqi Li, Xi Li, Hai Lu, Mingyi Hung, Steven Matsunaga, Dan Segal, and Yoonseok Zang. We also thank the conference participants at the 2012 American Accounting Association Annual Meeting, the 2012 FMA Annual Meeting, the 2012 PBFEAM Conference, the 2013 FARS Midyear Meeting, and workshop participants at The Hong Kong University of Science and Technology, National Chiao Tung University, National Taiwan University, and Singapore Management University for their helpful comments. The authors acknowledge financial support from the School of Accountancy Research (SOAR) at Singapore Management University and from the National Science Council in Taiwan (NSC 1012410-H-006-044). The first author is thankful for a research award by the E. SUN Bank in Taiwan for the conduct of this work.

Editor's note: Accepted by Bin Ke.

Submitted: November 2012 
firm acquires a private operating firm. Although the original U.S. public shell firm survives, the original private firm's shareholders maintain control. ${ }^{1}$ Since the 1990s, RMs have been the most popular alternative to IPOs for firms to go public in the U.S. (e.g., Floros and Shastri 2009a). In recent years, many foreign firms, particularly those from China, have entered the U.S. equity markets via RMs. Overall, there were 448 Chinese RM deals in the 2000-2011 period. ${ }^{2}$ About 72 percent of all foreign RM firms are from China, and over 90 percent of those listed on major U.S. stock exchanges are Chinese RM firms.

Despite its popularity, the RM process has been criticized as a "backdoor" or "shortcut" to going public, because RM firms bypass the scrutiny of the Securities and Exchange Commission (SEC) in the listing process. Many observers suspect that foreign RMs only "rent" the benefits of being listed in the U.S., without actually improving their corporate governance or financial reporting quality. These concerns are particularly noteworthy for Chinese RM firms, which are subject to weaker legal enforcement and investor protection. In 2010 and 2011, many Chinese RM firms restated their financial statements, and many shareholders sued Chinese RM firms for fraudulent accounting (e.g., Siegel and Wang 2013). These scandals triggered a rapid decline in the value of Chinese RM firms. From mid-2010 to mid-2011, these firms lost 80 percent of their market value (Templin 2012).

In this paper, we examine whether the low financial reporting quality of Chinese RM firms is related to their use of the less scrutinized RM method (i.e., the RM effect), the weak legal enforcement over Chinese firms (i.e., the weak country effect), or both. If the RM effect is significant, then we should expect both U.S. and Chinese RM firms to have lower financial reporting quality than their respective counterparts (i.e., U.S. IPO firms and Chinese ADR firms). If the weak country effect is significant, then we should expect Chinese RM firms to have lower financial reporting quality than U.S. RM firms. Relying on the crosslisting literature, we further hypothesize that the less scrutinized RM process allows Chinese firms with weaker bonding incentives to access the U.S. capital markets. In that case, Chinese RM firms should show poorer corporate governance and lower financial reporting quality than Chinese ADR firms.

We investigate these questions by analyzing a sample of 287 Chinese RM firms that are traded on U.S. stock exchanges or the over-the-counter (OTC) bulletin board and have the relevant data available. Due to the inherent difficulty in capturing financial reporting quality, we follow previous research (e.g., Dechow, Ge, and Schrand 2010; Hope, Thomas, and Vyas 2013) and use a wide range of measures, namely, the likelihood of accounting restatements and four accrual-based measures. To ensure that the differences in financial reporting quality are not driven by differences in firm characteristics, we control for a comprehensive list of factors that affect financial reporting quality.

We document three major empirical results. First, we find that the financial reporting quality of U.S. RM firms is comparable with that of U.S. IPO firms matched by their trading venue, industry, year, and size. However, the financial reporting quality of Chinese RM firms is lower than that of Chinese ADR firms. This result is interesting because the conditions of legal enforcement are the same for both Chinese RM and ADR firms, and the regulatory requirement for ongoing disclosure is arguably more stringent for Chinese RM firms than for Chinese ADR firms. These results indicate that the RM effect is associated with lower financial reporting quality for Chinese firms, but not for U.S. firms.

Second, we find that the financial reporting quality of Chinese RM firms is lower than that of U.S. RM firms. Given that both types of firms adopt the same listing method (i.e., the RM process), this result indicates that among RM firms, those that are subject to weak legal enforcement have lower financial reporting quality. These results, combined with the above-described results, indicate that the less scrutinized RM process leads to lower financial reporting quality only when the RM firms are subject to weak legal enforcement. In other words, both the RM effect and the weak country effect contribute to the lower financial reporting quality of Chinese RM firms.

Third, we examine the differences in the strength of bonding incentives and corporate governance features between Chinese RM and Chinese ADR firms. Consistent with our prediction, we find that Chinese RM firms have lower CEO turnoverperformance sensitivity (a measure of bonding incentives) than Chinese ADR firms. Chinese RM firms also have higher insider ownership, lower foreign ownership, smaller boards, higher likelihood of CEO-chairman duality, and lower CEO option-based compensation. These findings indicate that Chinese RM firms have weaker bonding incentives and engage in fewer bonding activities than Chinese ADR firms. Last, but not least, we confirm that the likelihood of using RM transactions (as explained by the governance variables) is associated with the lower financial reporting quality of Chinese RM firms.

Based on these analyses, we conclude that firms self-select their listing choices (RM versus IPO), and the less scrutinized RM process allows foreign firms with weak bonding incentives and poor financial reporting quality to enter the U.S. markets. In contrast, foreign firms with stronger bonding incentives and better financial reporting quality tend to enter the U.S. capital markets via the IPO process. In other words, the self-selection of listing options reveals firm types and differential levels of

\footnotetext{
1 A public shell company is defined as a public registrant that has no operations or assets, or only nominal operations and assets (SEC Securities Act Release No. 33-8587 (July 15, 2005, available at https://www.sec.gov/rules/final/33-8587.pdf).

2 In contrast, during the same period, there were only 135 newly listed Chinese ADRs (American Depositary Receipt [ADR] firms) on major stock exchanges, and an additional 107 unsponsored (or Level 1) Chinese ADRs.
} 
financial reporting quality. This self-selection argument implies that the financial reporting quality of Chinese RM firms is lower than that of Chinese ADR firms. Note that we are not suggesting that the RM process causes lower financial reporting quality.

The above-stated analyses focus on the level of financial reporting quality, not on investors' perceptions of it. When we use the earnings response coefficient based on quarterly earnings announcements to capture investors' perceptions of financial reporting quality, we find that Chinese RM firms do not differ from other firms. However, we find that throughout the year, the market reacts less positively to the changes in earnings reported by Chinese RM firms.

This paper contributes to the literature in several important ways. First, it sheds light on why Chinese RM firms have lower financial reporting quality than U.S. IPO firms and, thus, answers the call for more research on the financial reporting quality of RM firms (Public Company Accounting Oversight Board [PCAOB] 2011). Our findings should be of interest to regulators engaged in designing rules to enhance the financial reporting quality of foreign RM firms and to those investors who trade on the shares of these firms.

Second, our paper contributes to the literature on the financial reporting quality of U.S.-listed foreign firms by investigating the effect of the most popular listing method in recent years, the RM, which has generally been excluded in prior research (Lang, Raedy, and Yetman 2003; Lang, Raedy, and Wilson 2006; Leuz 2006; Ndubizu 2007). In particular, the paper builds on and extends the Lang et al. (2006) study in several important dimensions. First and foremost, although Lang et al. (2006) compare the financial reporting quality of ADRs and U.S. domestic firms, we investigate why Chinese RM firms have lower financial reporting quality than U.S. IPO firms. Second, although one can infer from the conclusion of Lang et al. (2006) that weak legal enforcement and weak investor protection in China lead Chinese firms to have lower financial reporting quality than U.S. firms (i.e., the weak country effect), their analysis does not shed light on the RM effect. Our analyses enhance our understanding of how the RM process affects U.S. firms and Chinese firms in different ways. Furthermore, we document that Chinese RM firms have weaker bonding incentives and poorer corporate governance than Chinese ADR firms, and that these differences contribute to the lower financial reporting quality of Chinese RM firms.

Third, this paper contributes to the cross-listing literature (Licht 2003; Siegel 2005; Lang et al. 2006). Our analysis of Chinese RM and ADR firms is particularly interesting because it highlights the importance of listing choices. Our results suggest that when alternative listing choices are available, some firms choose the more stringent IPO listing method, adopt better corporate governance mechanisms, and improve their financial reporting quality. Other firms choose the less stringent RM listing method to bypass the scrutiny of regulators and the market.

This paper is related to several concurrent studies that examine various issues surrounding Chinese RM firms, but our paper differs from these studies in several significant ways. By focusing on the fundamentals, Lee, Li, and Zhang (2015) find that Chinese RM firms are more likely to survive and perform better than other RM firms or exchange-industry-size matched U.S. firms. Like Lee et al. (2015), we also find that Chinese RM firms have better accounting performance (ROE) than U.S. RM firms or matched U.S. IPO firms. However, our paper complements that of Lee et al. (2015) by addressing related, but different, research questions. While Lee et al. (2015) focus on the performance of Chinese RM firms, we focus on the financial reporting quality of these firms. ${ }^{3}$ Better performance does not necessarily imply better financial reporting quality (Ang, Jiang, and Wu 2016; Darrough, Huang, and Zhao 2015).

Our paper is closely related to a concurrent study, namely, that of Givoly, Hayn, and Lourie (2014), who also find that Chinese RM firms have lower financial reporting quality than matched U.S. IPO firms. These authors attribute their finding to the broad cultural and institutional differences between the U.S. and China, without providing any direct evidence. Unlike Givoly et al. (2014), we conduct a more comprehensive analysis. In addition, we compare Chinese RM and Chinese ADR firms in terms of bonding incentives and corporate governance. Overall, our findings suggest that the lack of scrutiny associated with the RM process enables the firms with weak bonding incentives from China to list in the U.S., and that such practice contributes to low financial reporting quality.

Siegel and Wang (2013) also examine the governance and reporting quality of RM firms. They find that early adopters of RMs and RM firms hiring a Big 4 auditor exhibit superior corporate governance outcomes, including a lower likelihood of restatements. However, their study differs from our paper in three important dimensions. First, Siegel and Wang (2013) focus on the variations within non-U.S. RM firms, and they do not investigate the difference between these RM firms and other types of firms (e.g., U.S. IPO firms, Chinese ADR firms, or U.S. RM firms). Second, Siegel and Wang (2013) include both RMs involving shells and RMs involving two operating companies. For example, more than half of the RM firms in their sample are

\footnotetext{
3 There are also several other studies on Chinese RM firms, but these studies do not examine financial reporting quality issues. For example, Darrough et al. (2015) examine the spillover effects of Chinese firms that have been implicated in fraud. They find that Chinese firms that were not implicated in fraud also experienced a significant drop in stock prices in late 2010 and early 2011. He, Wong, and Young (2013) and Ang et al. (2016) arrive at a similar conclusion, and they show that many Chinese firms were delisted after the 2010-2011 drop in stock prices.
} 
Canadian RM firms, the majority of which are not RM firms involving shell companies. In contrast, our paper and other concurrent studies focus on RMs involving shells. Last, unlike Siegel and Wang (2013), we examine how firm-level governance affects firms' listing choices, and how these choices relate to financial reporting quality. As such, Siegel and Wang (2013) and the above-mentioned studies, including ours, complement each other.

The rest of this paper is organized as follows. Section II discusses the background of Chinese RM firms, reviews the related research, and develops the hypotheses. Section III explains the sample selection, variable measurements, and descriptive statistics. Section IV presents the empirical results with regard to the financial reporting quality of Chinese RM firms. Section V reports our analysis concerning the strength of the bonding incentive among U.S.-listed Chinese firms, and how this incentive relates to financial reporting quality. Section VI examines the market perception of financial reporting quality. Section VII concludes.

\section{BACKGROUND, RELATED RESEARCH, AND HYPOTHESIS DEVELOPMENT}

\section{Background on Chinese RM Firms}

Foreign firms, including Chinese firms, have various incentives for seeking access to U.S. capital markets. The most frequently cited reasons are to obtain cheaper capital and increase liquidity (e.g., Pagano, Röell, and Zechner 2002; Licht 2003). Other benefits include an increased shareholder base, greater visibility, growth, diversification, and economies of scale. As noted by the SEC's (2011) Investor Bulletin: Reverse Mergers, obtaining access to the U.S. capital markets also improves a company's reputation with its customers and potential acquirers. Finally, in China, having a company listed on a U.S. stock exchange is sometimes regarded as a trophy that increases the CEO's social status (Gillis 2011). In a similar vein, Hung, Wong, and Zhang (2012) find that state-owned enterprises with strong political connections are more likely to list on overseas exchanges because it can increase the managers' private benefits, such as receiving media coverage and being promoted to senior government positions. All of these potential benefits prompt Chinese firms to list in the U.S.

In recent years, the RM has become the most popular method for foreign firms, including Chinese firms, to go public in the U.S. In a typical Chinese RM transaction, a U.S. public shell company acquires a Chinese private firm through a share exchange. The U.S. public firm survives, but its directors and managers are replaced by the executives of the Chinese private firm. One of the reasons for the recent popularity of RMs is that compared with other approaches (e.g., IPOs), the RM process is faster and cheaper. Adjei, Cyree, and Walker (2008) estimate that the cost of setting up a public shell company and completing the RM transaction can be as low as $\$ 50,000$, compared to the millions of dollars it can cost to complete an IPO. Also, a typical RM can be done within six months. In contrast, an IPO commonly takes nine to 12 months to complete, and the process can be cancelled if the market situation changes unfavorably. Therefore, smaller, younger, and less profitable firms are more likely to undertake RM transactions (Adjei et al. 2008; Jindra, Voetmann, and Walkling 2012). Thus, despite the disadvantages of RMs, such as less access to funding, less support from market intermediaries, and being traded on the OTC market (Feldman 2009), the number of RM firms has grown rapidly in the past decade.

Interestingly, the RM approach to accessing the U.S. capital markets is particularly popular among Chinese firms as compared to other foreign firms. There are two possible reasons for this phenomenon. First, Chinese private firms have difficulties raising capital in China. According to the Organisation for Economic Co-operation and Development Economic Survey (OECD 2010), most Chinese private firms have difficulty accessing bank credit because Chinese banks focus mainly on the financing needs of large state-owned enterprises and on policy-directed lending. The still-developing bond markets are dominated by bonds issued by the central government and the central bank. In 2013, corporate bonds accounted for only 2.4 percent of the bond market. Even though the domestic stock markets have grown rapidly, private firms still have difficulties being listed on the Shanghai or Shenzhen stock exchanges due to the high standards required for listing. ${ }^{4}$ These requirements prevent many small or medium-sized Chinese firms from raising capital from the public in China.

Second, Feldman (2009) argues that U.S. investors have shown a strong desire to tap into China's fast-growing economy in recent years. To fulfill the strong demand from the market, some Wall Street bankers provide services that include accounting, legal advice, auditing, and public relations to encourage and prepare Chinese firms to enter the U.S. and raise capital there. Both the desire of U.S. investors to gain from China's economic growth and the institutional support provided attract Chinese firms to adopt the RM approach for entering the U.S. capital markets.

Since 2010, however, Chinese RM firms, especially those listed on the major stock exchanges, have drawn significant attention due to their large number of accounting fraud cases. In early 2011, the SEC suspended trading of several Chinese RM firms' shares and revoked the securities registrations of several others, primarily due to financial reporting concerns. Similarly,

\footnotetext{
${ }^{4}$ For example, to be qualified for listing on the main board or the small firm board, a firm must have been in business for more than three years and have made profits over the last three consecutive years, with cumulative profits of more than 30 million yuan.
} 
high-profile short-sellers have also targeted some Chinese RM firms. For example, in January 2011, J Capital Research issued a research report on China Green Agriculture, Muddy Waters on Sino-Forest in June 2011, and Citron Research on several Chinese RM firms in 2011. In response to these issues, the SEC issued a bulletin in July 2011 to warn investors concerning the dangers of investing in RM firms. In the same year, the Public Company Accounting Oversight Board (PCAOB) issued a research note highlighting problems with Chinese RM firms, particularly the growing concerns over these firms' audit quality.

Many commentators and regulators attribute these issues to the speed of the RM process and the loopholes in its requirements. ${ }^{5}$ Unlike the IPO process, which provides ample opportunities for information dissemination, such as road shows and detailed prospectuses, less time is provided for investors and the SEC to evaluate a firm during the RM process. ${ }^{6}$ Although IPO firms must file financial reports with the SEC for approval before going public, firms conducting RMs are only required to file their consolidated financial reports (Super 8-Ks) after the transaction. In addition, a Super 8-K is not as detailed as a prospectus. A Super 8-K usually provides information for the past two years, but a prospectus typically provides information for the past five years. In addition, many Super 8-Ks lack complete and detailed financial statements.

The protection that investors have against false financial statements is also much weaker in the RM than in the IPO process. As IPO cases involve the issuance of new shares, investment banks are also responsible for the representational faithfulness of the financial statements. In contrast, no underwriters are involved in RM cases, and most of the law firms or auditors involved in RM deals are small. The scrutiny from financial analysts and institutional investors is also lacking because most RM firms are traded on the OTC market.

It is important, however, to distinguish between the regulatory requirements for the listing process and the requirements for ongoing reporting. Although the RM process is characterized by weak scrutiny, RM firms are subject to the same regulatory requirements for ongoing financial reporting as firms that go public via IPOs (Licht, Poliquin, Siegel, and Li 2013). For example, on CNBC's Fast Money, the CEO of the NASDAQ OMX Group, Bob Greifeld, emphasized that the regulatory requirements and auditing standards for Chinese RM firms are identical to those for other listed firms. Please refer to Templin (2012) for more detailed discussions on the regulatory and legal issues related to Chinese RM firms.

\section{Related Research}

This paper is broadly related to the cross-listing literature, and particularly to those studies that examine the effects of cross-listing on financial reporting quality. There is a long line of research that examines the effects of cross-listing on foreign firms' corporate decisions and on firm value (e.g., Coffee 2002; Licht 2003; Doidge, Karolyi, and Stulz 2004; Siegel 2005; Leuz 2006; Doidge, Karolyi, Lins, Miller, and Stulz 2009). The majority of these studies are built on the bonding hypothesis (e.g., Coffee 1999; Stulz 1999), which states that firms with poor minority shareholder protection signal their desire to respect shareholder rights by listing in a jurisdiction with higher market scrutiny, tougher regulations, and better enforcement.

In terms of the relationship between cross-listing and financial reporting quality, Lang et al. (2003) find that firms crosslisted in the U.S. reflect bad news in a more timely manner, have a higher correlation between earnings and share prices, and are less likely to engage in earnings management than firms listed only in their home countries. Bailey, Karolyi, and Salva (2006) also document that cross-listed firms have higher earnings response coefficients (ERCs) than firms that are not cross-listed.

In addition to comparing cross-listed firms with firms listed in their own countries, previous studies have examined the financial reporting quality of cross-listed firms relative to U.S. domestic firms. For example, Lang et al. (2006) find that crosslisted firms are more likely to engage in earnings management than U.S. domestic firms. Ndubizu (2007) finds similar evidence, particularly for periods surrounding the time of cross-listing.

\section{Hypothesis Development on the Financial Reporting Quality of Chinese RM Firms}

In this section, we develop the hypotheses on why Chinese RM firms have lower financial reporting quality than U.S. IPO firms. Our argument is largely built on the cross-listing literature as discussed above. Prior research suggests three primary factors that can affect the financial reporting quality of foreign firms listed in the U.S.:

\footnotetext{
5 For example, in April 2011, Luis Aguilar, one of the SEC's commissioners, commented that "There are a lot of different ways for companies to access the public markets, but not all of them are equal. They differ in the quality of the disclosures, the time investors and the SEC typically have to consider them, and the protections that investors have against false and fraudulent statements ... In the world of backdoor registrations to gain entry into the U.S. public market, the use by Chinese companies has raised some unique issues ... There appear to be systematic concerns with the quality of the auditing and financial reporting" (Aguilar 2011).

6 An RM transaction can progress so fast that it is possible for an RM firm to be listed on a major stock exchange before the required financial statement is filed with the SEC. For example, the Chinese firm SinoCoking merged into a shell company named Alleauctions.com on February 5, 2010. Three days later, the Form 8-K was filed and the company was quoted on the OTC market. Thirteen days later, the stock was uplisted to the NASDAQ. However, it was not until March 18 that SinoCoking amended its 8-K filings to include the required audited financial statements.
} 
1. Enhanced disclosure requirements and market scrutiny in the U.S. These accountability structures are the foundations of the bonding mechanism that can improve the financial reporting quality of cross-listed foreign firms compared to their counterparts in their home countries (e.g., Lang et al. 2003; Leuz 2006; Gong, Ke, and Yu 2013). However, as we are not comparing Chinese firms listed in the U.S. with those listed in China, this factor is not particularly relevant for most of our analyses.

2. Investor protection in the home country and SEC enforcement over U.S.-listed foreign firms. For foreign firms from countries with weak investor protection, being listed in the U.S. can improve their financial reporting quality. However, the combination of weak investor protection in their home countries and weak SEC enforcement over foreign firms can reduce these firms' bonding incentives and lead to lower financial reporting quality compared to their U.S. counterparts (e.g., Lang et al. 2003; Siegel 2005; Leuz 2006; Gong et al. 2013).

3. Listing choices, firm-level bonding incentives, and governance. How a foreign firm accesses the U.S. capital markets can affect its financial reporting quality due to differences in the levels of scrutiny during the listing process. What is particularly relevant for this paper is whether the use of the RM method is associated with lower financial reporting quality. Although some firms choose the RM process because it is cheaper and faster, others might choose it because the scrutiny is less stringent. Therefore, firms with weaker bonding incentives and poorer governance may choose the RM process over the IPO process. Many studies argue that a firm's incentives and governance have more significant effects on its financial reporting quality than the accounting rules in general (e.g., Ball, Robin, and Wu 2003; Chi, Dhaliwal, Li, and Lin 2013), and that this is especially the case for foreign firms listed in the U.S. (Leuz 2006).

Below, we elaborate on the effects of these factors whenever they are applicable.

\section{The RM Effect}

As discussed above, the potential loopholes associated with the RM process, particularly the lack of market and regulatory scrutiny, have drawn attention from both the investment community and regulators. The weak scrutiny by regulators and market participants, along with other problems with the RM process, can result in lower financial reporting quality for RM firms than for their counterparts. We are not suggesting that the RM process causes firms to reduce their financial reporting quality. Instead, we argue that firms choosing the IPO process tend to improve their financial reporting quality due to the more stringent listing standards, the more closely scrutinized process, and the concerns of auditors and underwriters over potential litigation. In contrast, the firms that select the RM process might not improve their financial reporting quality, as the registration process is less scrutinized. In addition, the less scrutinized RM process can attract firms with weak bonding incentives, again resulting in lower financial reporting quality for RM firms.

To isolate the RM effect for U.S. firms, we compare U.S. RM firms with U.S. IPO firms. As these two groups of firms differ only in their listing process, we expect that if the use of the less scrutinized RM process is the main driver for poor financial reporting quality, then U.S. RM firms should have lower financial reporting quality than U.S. IPO firms:

H1: Ceteris paribus, the financial reporting quality of U.S. RM firms is lower than that of U.S. IPO firms.

Similarly, both Chinese RM firms and Chinese ADR firms are subject to the same legal enforcement regimes (e.g., investor protection in China and the SEC's enforcement in the U.S.) and they differ only in their listing choices. Thus, if the use of the less scrutinized RM process is the main driver, then we hypothesize the following:

H2: Ceteris paribus, the financial reporting quality of Chinese RM firms is lower than that of Chinese ADR firms.

We note, however, that although the RM process is less scrutinized than the IPO-ADR process, Chinese RM firms are subject to more stringent regulatory requirements in terms of ongoing financial reporting and governance than Chinese ADR firms. ADRs are exempt from some requirements related to disclosure and corporate governance, such as the proxy and insider trading provisions of the Securities and Exchange Act of 1934, quarterly reporting requirements, and Regulation Fair Disclosure (e.g., Licht 2003; Leuz 2006). In addition, ADR firms do not need to prepare the full U.S. generally accepted accounting principles (GAAP) financial statements; they only need to prepare 20-Fs. In contrast, Chinese RM firms inherit the filing status of the U.S. shell firms, and they must file financial statements as frequently and provide disclosures that are as detailed as those required of U.S. IPO firms. These differences in regulatory requirements are likely to cause bias against finding evidence consistent with $\mathrm{H} 2$.

\section{The Weak Country Effect}

The weak country effect refers to the notion that U.S. regulators have difficulties in gathering evidence and U.S. investors have problems in protecting their legal rights in countries with weak investor protection (e.g., Cheng, Srinivasan, and Yu 2014; 
McMahon 2012). These problems are exacerbated by the lack of jurisdiction of the U.S. enforcement officials, and by the lack of intention and/or resources that local regulators have in monitoring and disciplining U.S.-listed firms (Jindra et al. 2012; Siegel and Wang 2013). ${ }^{7}$ These problems certainly apply to Chinese RM firms. Many Chinese RM firms openly admit that both investor protection and legal enforcement are weak. ${ }^{8,9}$ Templin (2012) notes that regulators have weak enforcement powers over not only Chinese RM firms, but also over their Chinese auditors. Templin argues that the Chinese auditors who usually carry out audit work for the U.S. auditors hired by Chinese RM firms are commonly short of skills, and sometimes have lower ethical standards. All of these problems can lead to poor financial reporting quality.

To study the weak country effect, i.e., the effect of weak legal enforcement on the financial reporting quality of Chinese firms, one needs to control for the listing choice. For this purpose, we compare the reporting quality of Chinese RM and U.S. RM firms. Both groups of firms go through the same listing process and are subject to the same financial reporting rules. If weak legal enforcement over Chinese RM firms leads to lower financial reporting quality, then we expect Chinese RM firms to have lower financial reporting quality than U.S. RM firms: ${ }^{10}$

H3: Ceteris paribus, the financial reporting quality of Chinese RM firms is lower than that of U.S. RM firms.

\section{Chinese RM Firms and Chinese ADR Firms: Bonding Incentives and Corporate Governance}

When a Chinese firm intends to access the U.S. capital markets, it can (to some extent) choose to use either the RM approach or another approach (e.g., ADR). ${ }^{11}$ In light of this potential self-selection issue, we examine the strength of the bonding incentives and corporate governance of Chinese RM and Chinese ADR firms to better understand why financial reporting quality differs between these two groups of firms. ${ }^{12}$

Ball et al. (2003) find that when the incentive for increasing financial reporting quality is low, stringent standards do not necessarily lead to high-quality financial reporting. Subsequent studies, such as Chi et al. (2013), also find that incentives rather than rules tend to determine financial reporting quality. As such, although Chinese RM and ADR firms are subject to the same legal enforcement and investor protection, their financial reporting quality depends on their bonding incentives.

The notion of the bonding mechanism originates from the idea that in the more developed capital markets, foreign firms voluntarily subject themselves to stringent regulations and accept close monitoring from market participants in exchange for cheaper capital. However, the effectiveness of legal bonding is affected by the strength of legal enforcement and the firms' bonding incentives. Legal enforcement actions against foreign firms are rare, and they often result in insignificant penalties (e.g., Siegel 2005; Licht et al. 2013). Such weak enforcement over foreign firms reduces the firms' incentives to improve corporate governance or to provide high-quality financial statements. To distinguish themselves from others, high-quality firms are likely to engage in a dynamic reputation-building process through which their managers gradually form a reputation for not expropriating minority shareholders. These firms build a sound reputation by, for example, voluntarily improving corporate

\footnotetext{
${ }^{7}$ For example, Jindra et al. $(2012,24)$ argue that although "the incidence of litigation appears higher for CRM [Chinese RM] firms, the cost of litigation as measured by dollar settlement amounts does not appear large, especially when compared to other settlements."

${ }^{8}$ For example, with respect to the weak U.S. enforcement, China Display Technologies, Inc., states on page 19 of its prospectus (Form SB-2 filed on January 17, 2008) that "It will be extremely difficult to acquire jurisdiction and enforce liabilities against our officers, directors and assets based in China. Substantially all of our assets will be located outside of the United States and our officers and directors will reside outside of the United States. As a result, it may not be possible for United States investors to enforce their legal rights, to effect service of process upon our directors or officers or to enforce judgments of United States courts predicated upon civil liabilities and criminal penalties of our directors and officers under Federal securities laws. Moreover, we have been advised that China does not have treaties providing for the reciprocal recognition and enforcement of judgments of courts with the United States. Further, it is unclear if extradition treaties now in effect between the United States and China would permit effective enforcement of criminal penalties of the Federal securities laws."

9 For example, with respect to weak investor protection in China, China Crescent Enterprises, Inc., stated on page 10 of its $10-\mathrm{K}$ for fiscal year 2010 that "as the Chinese legal system evolves rapidly, the interpretations of many laws, regulations, and rules are not always uniform, and enforcement of these laws, regulations and rules involve uncertainties which may limit legal protections available to you and us."

10 This weak legal enforcement and investor protection applies not only to Chinese RM firms, but also to Chinese ADR firms. In the empirical analysis section, we discuss in detail whether this factor alone explains the low financial reporting quality of Chinese RM firms.

11 All private firms can theoretically choose the RM approach because they do not need to obtain approval from security regulators in China. As for ADRs, based on our untabulated analyses, we find that only 15 firms in our sample (11 percent) are incorporated in China and obtain approval from Chinese security regulators to access the U.S. markets via ADRs (e.g., China Eastern Airlines, China Telecom). The rest of the ADR firms (89 percent) are incorporated in offshore centers such as the Cayman Islands and the Virgin Islands, and they do not need to obtain Chinese regulators' approval to issue shares overseas (e.g., Sina, Baidu, Youku). As such, a Chinese private firm can theoretically choose to be incorporated in offshore centers and access the U.S. capital markets via ADRs.

12 This type of self-selection differs from the other type of self-selection that needs to be controlled for. As discussed above, the RM process is a cheaper and faster process than the IPO process and, thus, smaller or poorly performing firms are more likely to use the RM process. These firm characteristics are also correlated with financial reporting quality. As such, we control for the confounding effect of these firm characteristics in the empirical analyses, as discussed below.
} 
governance or by hiring reputable auditors and investment bankers (Coffee 2002; Siegel 2005; Marosi and Massoud 2008; Carcello, Carver, Lennox, and Neal 2014).

We argue that the Chinese firms that have stronger bonding incentives and better financial reporting quality tend to enter the U.S. capital markets via the IPO process, because of the close scrutiny of the SEC and market participants and the involvement of reputable market intermediaries, such as auditors and underwriters. These IPO/ADR firms are likely to have strong bonding incentives because, as examined in Coffee (2002), the insiders of ADR firms enjoy an increased valuation premium and the existing shareholders can immediately benefit from the bonding. In contrast, the less scrutinized RM process allows Chinese firms with weaker bonding incentives and poorer financial reporting quality to enter the U.S. markets. Chinese RM firms have weak bonding incentives, likely because most of the insiders from the original private firms do not sell their shares after the RM transactions (Floros and Shastri 2009b). As such, they do not benefit from strong bonding.

Stulz (1999) argues that in a weak legal enforcement environment, adopting more effective corporate governance mechanisms can serve as a strong signal of a firm's bonding incentives. Therefore, we argue that the corporate governancerelated decisions made by U.S.-listed Chinese firms are tied to the strength of their bonding incentives. This argument implies that Chinese RM firms have weaker corporate governance than Chinese ADR firms.

In summary, this discussion implies that bonding incentives and corporate governance are weaker for Chinese RM firms than for Chinese ADR firms. Thus, our last set of hypotheses is as follows:

H4a: Ceteris paribus, Chinese RM firms have weaker bonding incentives than Chinese ADR firms.

H4b: Ceteris paribus, the strength of corporate governance is weaker in Chinese RM firms than in Chinese ADR firms.

\section{SAMPLE AND DATA}

\section{Sample Selection}

We rely on multiple sources to compile our sample of Chinese RM firms. We start with the list of Chinese RM firms from DealFlow Media, which tracks RM deals with U.S. shell companies starting from 2001. From the records of DealFlow Media, we identify 432 RM deals involving Chinese private companies in the 2001-2011 period. We then cross-check this list with Chinese RM firms listed on the NYSE, the NYSE-AMEX, and the NASDAQ based on a Bloomberg report published in June 2011, and a record of U.S.-listed Chinese firms included in the Halter USX China Index and in reports by CYNES.com. ${ }^{13}$ To ensure that these firms are listed through the RM method, we go through these firms' annual filings and their websites. These steps yield 16 additional Chinese RM firms, resulting in our initial sample of 448 Chinese RM firms in the 2000-2011 period.

To be included in our final sample, Chinese RM firms need to satisfy the following criteria: (1) the headquarters of the firm and the majority of its operations are in China; (2) SEC filings (i.e., the first 10-K and 8-K filings) are available to verify whether a U.S. shell company is involved $;^{14}$ (3) the firms are not in the financial (SIC 6000-6999) or utilities (SIC 4900-4949) industries; (4) accounting data are available from Compustat or 10-K filings. As a result, six, four, 45, and 106 firms are excluded due to the above four requirements, respectively. Our final sample, therefore, includes 287 Chinese RM firms. Of these firms, 116 eventually listed on the major exchanges, and 171 were still traded on the OTC market at the time of data collection. $^{15}$

Note that to increase the generalizability of the results, we include both firms traded on the major stock exchanges and on the OTC market. The drawback to including OTC firms is that these firms are, on average, much smaller than those traded on the major stock exchanges. Firms traded on the OTC market are also subject to less stringent market monitoring. These differences are likely to introduce noise to the analyses. To mitigate this effect, we match the control firms by their trading

13 The Halter USX China Index includes Chinese firms that are listed on the NYSE, NYSE-AMEX, or the NASDAQ, and have a market-cap greater than $\$ 50$ million. The components of the Halter Index are updated quarterly based on the basic market value requirement and other factors. To avoid a survivorship bias, we collect a historical list of Chinese issues from quarterly reports of the Halter USX China Index since 2003.

14 We limit our sample to RM firms with shell firms for two reasons. First, an RM transaction between two operating firms is similar to a regular merger and acquisition, except that it is the target (not the acquirer) that survives. A lot of reputable firms have been established through this method, including Blockbuster, the NYSE, Texas Instruments, and Berkshire Hathaway. However, the primary objective of RMs involving shell firms is for the private firms to go public. Second, the majority of the U.S. RM deals in our sample period are conducted through merging with shell firms. Therefore, focusing on RMs with shell firms can facilitate a more appropriate comparison.

15 Compustat covers firms traded on the OTC market only if their shares are priced at $\$ 0.01$ or above, and are traded fairly consistently. For OTC-traded Chinese RM firms not covered by Compustat, we hand-collect data from their 10-K filings. To ensure that our results are not affected by extremely small firms, we limit the scope of data collection to firms with positive common shareholders' equity, non-zero sales, and with total assets of $\$ 1$ million or more. 
venue, as is discussed in detail later. We also conduct an untabulated sensitivity test by excluding OTC firms from the sample, and find quantitatively similar results.

The sample selection process for U.S. RM firms is similar. From DealFlow Media, we identify 1,204 RM deals involving U.S. shell companies. Applying the same criteria as previously described, we obtain 273 U.S. RM firms. Of these, 65 have uplisted to major stock exchanges and 208 are still traded on the OTC market.

We collect Chinese ADRs based on information available from the Bank of New York, JPMorgan at: https://www.adr. com/, CYNE.com, Sina.com's historical quarterly reports, and the Halter USX China Index. We read the 20-F filings of Chinese ADR firms to identify the locations of their headquarters and businesses and to ensure that these firms are from China. We do not include ADRs traded on the OTC market because they are exempt from the SEC reporting requirements. ${ }^{16}$ These steps result in a sample of 142 Chinese ADRs.

In addition to accounting data from Compustat, we obtain the price and return data from the Center for Research in Security Prices (CRSP) and the restatement data from Audit Analytics. We hand-collect CEO turnover and corporate governance variables for Chinese RM and ADR firms from their 10-Ks, 20-Fs, and proxy statements filed with the SEC.

Panel A of Table 1 reports the yearly distribution of Chinese RM firms, U.S. RM firms, and Chinese ADRs. ${ }^{17}$ The greatest number of Chinese RM deals happened in the 2004-2010 period. Panel B of Table 1 presents the distribution based on the trading venue at the time of data collection. Chinese RM firms are more likely to be traded on the major exchanges than U.S. RM firms. Also, a disproportionally higher percentage of Chinese ADR firms (67 out of 142) are listed on the NYSE; the results are quantitatively similar when we control for exchange fixed effects in all regressions. Panel $\mathrm{C}$ of Table 1 presents the sample distribution by Fama-French industry classification. Most of the U.S.-listed Chinese firms are from the business equipment, manufacturing, healthcare, or wholesale and retail industries. Most of the U.S. RM firms are in the business equipment, healthcare, or consumer non-durables industries.

To test H1, we need a sample of U.S. IPO firms. As small and poorly performing firms tend to use the RM process to access the capital markets, and as these firm characteristics are correlated with financial reporting quality, we use two approaches jointly to control for this potential self-selection issue. First, we use U.S. IPO firms matched on the trading venue (NYSE, NASDAQ, AMEX, or OTC), industry, year, and size as control firms. Second, as discussed below, we include a comprehensive list of variables that prior research shows to affect financial reporting quality as the control variables. We believe that these two approaches address the potential confounding effects of the differences in firm fundamentals between RM and IPO firms, and that the documented results capture the RM effect on financial reporting quality for U.S. firms.

We use the same methodology to identify matched U.S. IPO firms for Chinese RM firms.

\section{Measurement of Financial Reporting Quality}

As there are no universally accepted measures of financial reporting quality, we use a wide range of measures to triangulate our results (Dechow et al. 2010). The use of multiple measures also helps to capture the different aspects of financial reporting quality. Specifically, we use both the probability of accounting restatements and several accrual-based measures to capture financial reporting quality. These measures have been used widely in accounting studies. One benefit of using the probability of accounting restatements is that it is subject to fewer measurement error issues. The drawback of this measure is that it is influenced by the effectiveness of the detection of the earnings management that ultimately leads to restatements. To the extent that Chinese RM firms have weaker bonding incentives (which can reduce the effectiveness of detection), we might not be able to find results consistent with $\mathrm{H} 2$ and $\mathrm{H} 3 .{ }^{18}$ The analysis of accrual-based financial reporting quality measures, therefore, complements the analysis of restatements. While the accrual-based measures are likely to capture earnings management tactics within the GAAP boundaries, restatements can capture financial reporting activities beyond such boundaries (Lang et al. 2006). As such, consistent results from these analyses can enhance our confidence in the inferences.

\footnotetext{
${ }^{16}$ ADRs (sponsored or unsponsored) that trade on the OTC market are exempt from Section 12g3-2(b) of the Security Exchange Act of 1934 registration and reporting requirements. There is also no reconciliation between financial statements prepared under the local GAAP and the U.S. GAAP. As such, the financial statements of these firms are based on local GAAP and are not comparable with those of other firms (e.g., Chinese RM firms). In addition, these firms are not under U.S. jurisdiction. See the SEC's (2012) Investor Bulletin: American Depositary Receipts for discussions of the disclosure and reporting requirements on ADR firms.

17 There are three Chinese RM firms and 21 Chinese ADR firms that were listed before 2001. Data for U.S. RM firms involving shell firms before 2001 are not available from DealFlow Media. Excluding these 24 Chinese firms from the sample does not affect the results.

18 Srinivasan, Wahid, and $\mathrm{Yu}$ (2015) find that the restatement frequency of foreign firms listed on U.S. exchanges is lower than that of U.S. firms. Furthermore, they find that there is no positive association between restatement frequency and internal control weaknesses for foreign firms from countries with weak rule of law. They interpret these results as indicating that weak rule of law negatively affects the likelihood of detecting and reporting accounting misstatements.
} 
TABLE 1

Descriptive Statistics of Chinese RM Firms, U.S. RM Firms, and Chinese ADR Firms

Panel A: Sample Distribution by the Year of Listing

\begin{tabular}{lcccc} 
First Listing Year & $\begin{array}{c}\text { Chinese } \\
\text { RM Firms }\end{array}$ & & $\begin{array}{c}\text { U.S. } \\
\text { RM Firms }\end{array}$ & \begin{tabular}{c}
$\begin{array}{c}\text { Chinese } \\
\text { ADR Firms }\end{array}$ \\
\cline { 2 - 2 } 2000 and earlier
\end{tabular} \\
\cline { 2 - 3 } 2001 & 3 & 0 & 21 \\
2002 & 2 & 3 & 5 \\
2003 & 8 & 12 & 1 \\
2004 & 22 & 49 & 0 \\
2005 & 29 & 48 & 8 \\
2006 & 47 & 38 & 7 \\
2007 & 54 & 36 & 11 \\
2008 & 46 & 15 & 20 \\
2009 & 33 & 17 & 14 \\
2010 & 34 & 12 & 26 \\
2011 & 8 & 273 & 16 \\
Total & 287 & & 142
\end{tabular}

This panel reports the distribution of sample firms based on the year when their shares were first listed in the U.S. stock markets.

Panel B: Sample Distribution by Exchanges at the Time of Data Collection

\begin{tabular}{|c|c|c|c|c|c|}
\hline Firm Type & NYSE & NASDAQ & AMEX & OTC & Total \\
\hline Chinese RM firms & 6 & 82 & 28 & 171 & 287 \\
\hline U.S. RM firms & 4 & 39 & 22 & 208 & 273 \\
\hline Chinese ADR firms & 67 & 74 & 1 & 0 & 142 \\
\hline Total & 77 & 195 & 51 & 379 & \\
\hline
\end{tabular}

\section{Panel C: Sample Distribution by Fama-French Industry Classification}

\begin{tabular}{l} 
Industry \\
\hline Consumer Non-Durables \\
Consumer Durables \\
Manufacturing \\
Oil, Gas, and Coal Extraction and Products \\
Chemicals and Allied Products \\
Business Equipment \\
Telephone and Television Transmission \\
Wholesale, Retail, and Some Services \\
Healthcare, Medical Equipment, and Drugs \\
Others \\
Total
\end{tabular}

\begin{tabular}{ccc}
$\begin{array}{cc}\text { Chinese } \\
\text { RM Firms }\end{array}$ & & $\begin{array}{c}\text { U.S. } \\
\text { RM Firms }\end{array}$ \\
36 & & 12 \\
13 & & 8 \\
55 & & 23 \\
7 & & 27 \\
19 & & 9 \\
40 & & 58 \\
4 & & 7 \\
34 & & 15 \\
38 & & 54 \\
41 & & 60 \\
\hline 287 & & 273
\end{tabular}

\begin{tabular}{c}
$\begin{array}{c}\text { Chinese } \\
\text { Non-RM Firms }\end{array}$ \\
\hline 8 \\
3 \\
9 \\
5 \\
4 \\
58 \\
6 \\
8 \\
11 \\
30 \\
\hline 142
\end{tabular}

We collect information on restatements from Audit Analytics, which covers the restatements announced since 2000. We include all restatements on which data are available in the sample. In addition, we separate errors from accounting irregularities. To identify accounting irregularities, we follow the procedure outlined by Hennes, Leone, and Miller (2008) and cross-check with the fraud cases listed in Jindra et al. (2012), Siegel and Wang (2013), and Ang et al. (2016).

We use four accrual-based financial reporting quality measures. The following is a brief description. (Please see Appendix A for a more detailed discussion.) The first measure is the absolute value of discretionary accruals $(|D A|)$, which is estimated from the Jones model as modified in Dechow, Sloan, and Sweeney (1995). The second measure is 
based on the cross-sectional Dechow and Dichev (2002) model, as modified in McNichols (2002), Francis, LaFond, Olsson, and Schipper (2005), and Ball and Shivakumar (2006). The absolute value of the residual from the regression $(|D D|)$ is used as a proxy for financial reporting quality. The third measure is the absolute value of discretionary revenue $(|D R|)$, which is the residual estimated from a regression of accounts receivable on the change in revenue, as developed by McNichols and Stubben (2008) and Stubben (2010). The fourth measure is based on the natural logarithm of the ratio of the absolute value of accruals to cash flows, $\ln |A C C R / O C F|$, as developed and used by Burgstahler, Hail, and Leuz (2006) and Hope et al. (2013). Firms may overstate earnings without affecting cash flows to achieve certain earnings targets or to report good performance in specific instances through accrual choices. The higher the ratio, the lower the financial reporting quality.

We also conduct a principal component analysis to capture the common construct underlying the four accrual-based financial reporting quality measures. We define the financial reporting index $(F R Q)$ as the principal component that has the highest eigenvalue. ${ }^{19}$

\section{Descriptive Statistics}

Table 2 reports the descriptive statistics for Chinese RM firms, U.S. RM firms, Chinese ADR firms, and the matched U.S. IPO firms. Panel A reports the distribution of restated firm-years for the full sample and by year. Chinese RM firms have a much higher likelihood of restatements (23 percent) than U.S. RM firms (9 percent), Chinese ADR firms (5 percent), or matched U.S. IPO firms (13 percent). There is no obvious year effect.

Panel B of Table 2 reports descriptive statistics on other variables. Chinese RM firms have a higher likelihood of both errors and accounting irregularities. They also have lower financial reporting quality than other types of firms, according to the accrual-based measures. In terms of the control variables used in the financial reporting quality analysis, we find that U.S. RM firms stand out as having the highest market-to-book ratio and sales growth. Like Lee et al. (2015), we find that Chinese RM firms outperform U.S. RM and IPO firms by having higher ROE. Chinese ADR firms also appear to be larger than other firms. Chinese RM firms have the highest capital needs, and the matched U.S. IPO firms have the lowest capital needs.

\section{FINANCIAL REPORTING QUALITY OF CHINESE RM FIRMS}

Due to research design differences, we first present the analysis of the likelihood of restatements, and then the analysis of accrual-based financial reporting quality measures.

\section{Analysis of the Likelihood of Restatements}

To test $\mathrm{H} 1 \sim \mathrm{H} 3$, we estimate the following logit regression:

$$
\begin{aligned}
\operatorname{Prob}_{\left(\text {Restatement }_{i t}\right)=} & \alpha+\beta_{1} \text { RM }_{i t}+\beta_{2} \text { China }_{i t}+\beta_{3} R M_{i t} \times \text { China }_{i t}+\gamma \text { Controls }_{i t-1}+\varphi \text { Year Dummies } \\
& +\theta \text { Industry Dummies }+\varepsilon_{i t}
\end{aligned}
$$

The dependent variable, Restatement, is a dummy variable that equals 1 if the financial statement of firm $i$ in year $t$ is restated later, and 0 otherwise. The RM firm indicator variable, RM, equals 1 for Chinese or U.S. RM firms, and 0 for U.S. IPO or Chinese ADR firms. The Chinese firm indicator variable, China, equals 1 for Chinese RM or ADR firms, and 0 for U.S. RM or IPO firms. The sample includes Chinese RM firms, U.S. RM firms, Chinese ADR firms, and matched U.S. IPO firms. ${ }^{20}$ The reported z-statistics are based on firm- and year-clustering adjusted standard errors. Under this specification, coefficient $\beta_{1}$ captures the difference in the likelihood of having accounting restatements between U.S. RM and U.S. IPO firms, i.e., the RM effect for U.S. firms. Coefficient $\beta_{2}$ captures the difference in the likelihood of accounting restatements between Chinese ADR and U.S. IPO firms, i.e., the weak country effect for ADR/IPO firms. Coefficient $\beta_{3}$ captures the incremental RM effect for Chinese firms, i.e., the incremental weak country effect for RM firms. As such, the RM effect for Chinese firms is captured by $\beta_{1}+\beta_{3}$, and the weak country effect for RM firms is captured by $\beta_{2}+\beta_{3}$. The interpretations of the coefficients and hypothesis testing are summarized as follows:

19 This is the only factor with an eigenvalue larger than 1 (2.4). It explains 48.5 percent of the sample variance and is positively correlated with each individual measure.

${ }^{20}$ Note that we include both the matched U.S. IPO firms for Chinese RM firms, as well as those for U.S. RM firms. The inferences remain the same if we only include the matched U.S. IPO firms for U.S. RM firms. In untabulated analyses, we also conduct pairwise comparisons (Chinese RM firms with matched U.S. IPO firms, U.S. RM firms with matched U.S. IPO firms, Chinese RM firms with Chinese ADR firms, and Chinese RM firms with U.S. $\mathrm{RM}$ firms) and the inferences are the same. We report the pooled regression results to simplify the presentation. 
TABLE 2

Descriptive Statistics on Financial Reporting Quality and Control Variables

Panel A: Yearly Distribution of the Likelihood of Accounting Restatements

\begin{tabular}{|c|c|c|c|c|c|c|c|c|c|c|}
\hline \multirow[b]{2}{*}{ Year } & \multicolumn{2}{|c|}{ Chinese RM Firms } & \multicolumn{2}{|c|}{$\begin{array}{c}\text { U.S. IPO Firms } \\
\text { Matched with } \\
\text { Chinese RM Firms }\end{array}$} & \multicolumn{2}{|c|}{ U.S. RM Firms } & \multicolumn{2}{|c|}{$\begin{array}{l}\text { U.S. IPO Firms } \\
\text { Matched with } \\
\text { U.S. RM Firms }\end{array}$} & \multicolumn{2}{|c|}{ Chinese ADR Firms } \\
\hline & $\mathbf{n}$ & Mean & $\mathbf{n}$ & Mean & $\mathbf{n}$ & Mean & $\mathbf{n}$ & Mean & $\mathbf{n}$ & Mean \\
\hline 2001 & 4 & 0.00 & 3 & 0.00 & 0 & NA & 0 & NA & 27 & 0.04 \\
\hline 2002 & 3 & 0.33 & 3 & 0.17 & 2 & 0.50 & 1 & 0.00 & 28 & 0.00 \\
\hline 2003 & 5 & 0.20 & 4 & 0.13 & 4 & 0.25 & 2 & 0.00 & 27 & 0.07 \\
\hline 2004 & 9 & 0.22 & 8 & 0.13 & 15 & 0.13 & 8 & 0.12 & 37 & 0.11 \\
\hline 2005 & 17 & 0.41 & 13 & 0.27 & 25 & 0.12 & 15 & 0.13 & 45 & 0.11 \\
\hline 2006 & 36 & 0.22 & 28 & 0.11 & 36 & 0.06 & 30 & 0.06 & 55 & 0.04 \\
\hline 2007 & 62 & 0.24 & 54 & 0.10 & 53 & 0.09 & 46 & 0.06 & 77 & 0.01 \\
\hline 2008 & 96 & 0.19 & 84 & 0.11 & 55 & 0.13 & 46 & 0.10 & 85 & 0.07 \\
\hline 2009 & 112 & 0.26 & 101 & 0.14 & 59 & 0.05 & 48 & 0.06 & 94 & 0.05 \\
\hline 2010 & 93 & 0.20 & 87 & 0.11 & 54 & 0.06 & 39 & 0.07 & 113 & 0.02 \\
\hline 2011 & 12 & 0.17 & 11 & 0.09 & 11 & 0.00 & 3 & 0.00 & 12 & 0.00 \\
\hline Total & 449 & 0.23 & 396 & 0.13 & 314 & 0.09 & 238 & 0.07 & 600 & 0.05 \\
\hline
\end{tabular}

This panel reports the distribution of the restated firm-years by year.

Panel B: Descriptive Statistics on Financial Reporting Quality and Control Variables

\begin{tabular}{|c|c|c|c|c|c|c|c|c|c|c|}
\hline & \multicolumn{2}{|c|}{ Chinese RM Firms } & \multicolumn{2}{|c|}{$\begin{array}{c}\text { U.S. IPO Firms } \\
\text { Matched with } \\
\text { Chinese RM Firms }\end{array}$} & \multicolumn{2}{|c|}{ U.S. RM Firms } & \multicolumn{2}{|c|}{$\begin{array}{l}\text { U.S. IPO Firms } \\
\text { Matched with } \\
\text { U.S. RM Firms }\end{array}$} & \multicolumn{2}{|c|}{ Chinese ADR Firms } \\
\hline & Mean & Median & Mean & Median & Mean & Median & Mean & Median & Mean & Median \\
\hline \multicolumn{11}{|l|}{ Dependent Variables } \\
\hline Restatement & 0.23 & 0.00 & 0.13 & 0.00 & 0.09 & 0.00 & 0.07 & 0.00 & 0.05 & 0.00 \\
\hline Error & 0.12 & 0.00 & 0.07 & 0.00 & 0.08 & 0.00 & 0.06 & 0.00 & 0.04 & 0.00 \\
\hline Irregularity & 0.11 & 0.00 & 0.06 & 0.00 & 0.01 & 0.00 & 0.01 & 0.00 & 0.01 & 0.00 \\
\hline$|D A|$ & 0.17 & 0.12 & 0.12 & 0.07 & 0.22 & 0.13 & 0.17 & 0.09 & 0.10 & 0.06 \\
\hline$|D D|$ & 0.18 & 0.13 & 0.05 & 0.02 & 0.13 & 0.07 & 0.08 & 0.04 & 0.09 & 0.05 \\
\hline$|D R|$ & 0.12 & 0.07 & 0.05 & 0.02 & 0.10 & 0.04 & 0.07 & 0.03 & 0.06 & 0.03 \\
\hline $\ln |A C C R / O C F|$ & -0.44 & -0.29 & -0.49 & -0.46 & -0.54 & -0.57 & -0.53 & -0.48 & -0.45 & -0.44 \\
\hline$F R Q$ & 0.68 & 0.33 & -0.10 & -0.29 & 0.42 & 0.11 & 0.24 & -0.02 & -0.38 & -0.58 \\
\hline \multicolumn{11}{|l|}{ Control Variables } \\
\hline$M / B$ & 2.99 & 1.40 & 3.56 & 1.50 & 5.90 & 3.79 & 4.52 & 2.33 & 2.56 & 1.58 \\
\hline Growth (\%) & 38.31 & 26.49 & 18.37 & 0.00 & 51.21 & 24.78 & 26.84 & 0.00 & 38.63 & 27.13 \\
\hline$L E V(\%)$ & 14.03 & 8.11 & 16.99 & 9.72 & 13.94 & 3.67 & 12.98 & 5.15 & 13.55 & 5.59 \\
\hline ROE (\%) & 6.17 & 15.86 & -5.49 & 0.50 & -19.51 & -36.21 & -13.56 & -18.28 & 8.34 & 10.27 \\
\hline Size & 4.29 & 4.44 & 4.26 & 4.27 & 2.99 & 2.94 & 2.91 & 2.83 & 6.51 & 6.04 \\
\hline Capital_Need (\%) & 19.21 & 0.00 & 4.66 & 0.00 & 9.46 & 0.00 & 6.83 & 0.00 & 9.59 & 0.02 \\
\hline Loss $(\overline{\%})$ & 13.91 & 0.00 & 43.44 & 40.00 & 35.70 & 33.33 & 49.27 & 45.45 & 12.92 & 0.00 \\
\hline Op_Cycle & 0.66 & 0.46 & 0.56 & 0.32 & 0.81 & 0.25 & 0.71 & 0.28 & 0.43 & 0.29 \\
\hline Inventory & 0.10 & 0.06 & 0.14 & 0.11 & 0.08 & 0.002 & 0.08 & 0.01 & 0.06 & 0.02 \\
\hline
\end{tabular}




\begin{tabular}{|c|c|c|c|}
\hline & IPO / ADR firms & RM firms & RM effect \\
\hline U.S. firms & & $\beta_{1}$ & $\begin{array}{l}\text { For U.S. firms: } \beta_{1} \\
\mathrm{H} 1: \beta_{1}>0\end{array}$ \\
\hline Chinese firms & $\beta_{2}$ & $\beta_{1}+\beta_{2}+\beta_{3}$ & $\begin{array}{l}\text { For Chinese firms: } \beta_{1}+\beta_{3} \\
\mathrm{H} 2: \beta_{1}+\beta_{3}>0\end{array}$ \\
\hline $\begin{array}{r}\text { Weak country } \\
\text { effect }\end{array}$ & For IPO/ADR firms: $\beta_{2}$ & $\begin{array}{l}\text { For RM firms: } \beta_{2}+\beta_{3} \\
\text { H3: } \beta_{2}+\beta_{3}>0\end{array}$ & $\begin{array}{l}\text { Difference in } \\
\text { differences: } \beta_{3}\end{array}$ \\
\hline
\end{tabular}

Control variables include the variables that prior research suggests affect financial reporting quality: the market-to-book ratio $(M /$ $B$ ), sales growth (Growth), leverage (LEV), firm size (Size), capital needs (Capital_Need), firm performance (ROE, Loss), operating cycle (Op_Cycle), and inventory (Inventory). ${ }^{21}$ Please see Appendix B for the definition of these variables. We also include industry and year dummies to control for the industry and year fixed effects. As such, we do not tabulate the coefficient on intercept.

Table 3 reports the regression results, with Model (1) of Panel A for the regression coefficients, and Panel B for hypothesis testing based on the likelihood of all restatements.

Before investigating why Chinese RM firms have lower financial reporting quality, we first confirm that they indeed have lower financial reporting quality than matched U.S. IPO firms. The difference in the likelihood of accounting restatements between Chinese RM and U.S. IPO firms is captured by $\beta_{1}+\beta_{2}+\beta_{3}$. As reported in Panel $\mathrm{B}$ of Table 3 , the sum of these three coefficients is significantly positive ( $\mathrm{z}=5.32$ ), indicating that Chinese RM firms indeed exhibit a higher likelihood of restatements than U.S. IPO firms.

\section{Test of H1 and H2: The RM Effect}

To test H1, we compare the financial reporting quality of U.S. RM firms with that of matched U.S. IPO firms to investigate whether the RM effect leads to lower financial reporting quality for U.S. RM firms. As discussed above, this effect is captured by the coefficient on $R M, \beta_{1}$. As reported in Table $3, \beta_{1}$ is insignificantly different from zero, suggesting that U.S. RM firms do not differ from matched U.S. IPO firms in the likelihood of restatements.

To test H2, we compare the financial reporting quality of Chinese RM firms with that of Chinese ADR firms. This effect is captured by the sum of the coefficient on $R M$ and that on the interaction term, $\beta_{1}+\beta_{3}$. As reported in Panel $\mathrm{B}$ of Table $3, \beta_{1}+$ $\beta_{3}$ is significantly positive $(\mathrm{z}=5.45)$. This result indicates that Chinese $\mathrm{RM}$ firms are more likely to have accounting restatements than Chinese ADR firms, which is consistent with $\mathrm{H} 2$, that the financial reporting quality of Chinese RM firms is lower than that of Chinese ADR firms.

As discussed above, we include Chinese RM firms traded on the major stock exchanges or on the OTC market, but for the Chinese ADR firms, we include only those traded on major stock exchanges due to data limitations. To ensure that the above results are not driven by the trading venue difference, we match Chinese RM firms with Chinese ADR firms based on their trading venue, industry, year, and size. The untabulated results are quantitatively similar.

In summary, the results from the tests of $\mathrm{H} 1$ and $\mathrm{H} 2$ indicate that although the RM effect does not lead to lower financial reporting quality for U.S. RM firms, it does for Chinese RM firms.

\section{Test of H3: The Weak Country Effect}

Next, we compare the financial reporting quality of Chinese RM firms with that of U.S. RM firms to investigate the weak country effect. As both groups of firms are subject to the same RM-related issues and filing rules, the difference between these two groups of firms, if any, should be driven by country-related factors such as legal enforcement and investor protection. As discussed above, the weak country effect for RM firms is captured by the sum of the coefficient on China and that on the interaction term, $\beta_{2}+\beta_{3}$. As reported in Panel B of Table $3, \beta_{2}+\beta_{3}$ is significantly positive $(\mathrm{z}=4.26)$. These results are consistent with $\mathrm{H} 3$, that the weak legal enforcement and weak investor protection for Chinese RM firms lead to lower financial reporting quality for Chinese RM firms. ${ }^{22}$

\footnotetext{
${ }^{21}$ In an untabulated sensitivity test, we also control for the standard deviation of quarterly earnings and obtain qualitatively similar results.

22 The arguments underlying our hypotheses imply that RM firms from all countries with weak legal enforcement and investor protection are likely to have lower financial reporting quality than U.S. IPO firms or ADR firms from the corresponding countries. However, it is challenging to test this prediction due to the data limitations - after imposing all the data requirements, there are only 22 firm-years from 12 foreign RM firms. Nevertheless, in an untabulated analysis, we find that foreign RM firms have similar financial reporting quality to that of foreign ADR firms and U.S. RM firms. However, these results should be interpreted with caution for two reasons: (1) the sample includes RM firms from different countries, some of which have strong investor protection, and (2) the sample size is very small. In addition, due to the small sample size, we cannot test whether RM firms from other foreign countries with lower investor protection and weaker enforcement have poor financial reporting quality.
} 


\section{TABLE 3 \\ Test of H1 $\sim \mathrm{H3}$ Analysis of Accounting Restatements}

Panel A: Regression Results

\begin{tabular}{|c|c|c|c|}
\hline & $\begin{array}{l}\text { All Restatements } \\
\text { (Model (1)) }\end{array}$ & $\begin{array}{c}\text { Errors } \\
(\text { Model (2)) }\end{array}$ & $\begin{array}{c}\text { Irregularities } \\
\text { (Model (3)) }\end{array}$ \\
\hline$R M$ & $\begin{array}{c}0.593 \\
(1.60)\end{array}$ & $\begin{array}{c}0.696 \\
(1.48)\end{array}$ & $\begin{array}{c}0.244 \\
(0.29)\end{array}$ \\
\hline China & $\begin{array}{l}-0.011 \\
(-0.02)\end{array}$ & $\begin{array}{l}1.577 * * \\
(2.57)\end{array}$ & $\begin{array}{l}-1.114 \\
(-0.82)\end{array}$ \\
\hline$R M \times$ China & $\begin{array}{l}1.475^{* * * *} \\
(2.65)\end{array}$ & $\begin{array}{l}-0.178 \\
(-0.24)\end{array}$ & $\begin{array}{l}3.399 * * * \\
(2.58)\end{array}$ \\
\hline$M / B$ & $\begin{array}{l}-0.002 \\
(-0.19)\end{array}$ & $\begin{array}{l}-0.016 \\
(-1.46)\end{array}$ & $\begin{array}{l}-0.026 \\
(-0.57)\end{array}$ \\
\hline Growth & $\begin{array}{l}0.100^{*} \\
(1.69)\end{array}$ & $\begin{array}{c}0.070 \\
(0.97)\end{array}$ & $\begin{array}{r}0.087 \\
(0.77)\end{array}$ \\
\hline$L E V$ & $\begin{array}{l}-0.305 \\
(-0.43)\end{array}$ & $\begin{array}{l}-0.765 \\
(-0.76)\end{array}$ & $\begin{array}{c}-0.982 \\
(-0.73)\end{array}$ \\
\hline$R O E$ & $\begin{array}{l}-0.202 \\
(-1.06)\end{array}$ & $\begin{array}{l}-0.416^{*} \\
(-1.88)\end{array}$ & $\begin{array}{l}-0.713 \\
(-1.41)\end{array}$ \\
\hline Size & $\begin{array}{l}-0.028 \\
(-0.33)\end{array}$ & $\begin{array}{l}-0.141 \\
(-1.33)\end{array}$ & $\begin{array}{r}0.272 \\
(1.64)\end{array}$ \\
\hline Capital_Need & $\begin{array}{c}0.256^{*} \\
(1.89)\end{array}$ & $\begin{array}{c}0.185 \\
(1.00)\end{array}$ & $\begin{array}{r}0.110 \\
(0.54)\end{array}$ \\
\hline Loss & $\begin{array}{c}0.237 \\
(0.52)\end{array}$ & $\begin{array}{c}0.912 \\
(1.59)\end{array}$ & $\begin{array}{l}-0.713 \\
(-0.85)\end{array}$ \\
\hline Op_Cycle & $\begin{array}{r}0.022 \\
(0.24)\end{array}$ & $\begin{array}{l}-0.031 \\
(-0.28)\end{array}$ & $\begin{array}{l}-0.346 \\
(-1.00)\end{array}$ \\
\hline Inventory & $\begin{array}{l}-0.168 \\
(-0.18)\end{array}$ & $\begin{array}{c}0.143 \\
(0.13)\end{array}$ & $\begin{array}{c}1.669 \\
(0.80)\end{array}$ \\
\hline Year effects & Yes & Yes & Yes \\
\hline Industry effects & Yes & Yes & Yes \\
\hline $\mathrm{n}$ & 1,997 & 1,938 & 1,997 \\
\hline Pseudo $\mathrm{R}^{2}$ & 0.178 & 0.171 & 0.253 \\
\hline
\end{tabular}

$* * *, * *, *$ Indicate statistical significance at the 1 percent, 5 percent, and 10 percent levels, respectively.

This panel reports the Logit regression of the probability of restatement on indicators for firm types and control variables:

$\operatorname{Prob}\left(\right.$ Restatement $\left._{i t}\right)=\alpha+\beta_{1} R M_{i t}+\beta_{2}$ China $_{i t}+\beta_{3} R M_{i t} \times$ China $_{i t}+\gamma$ Controls $_{i t-1}+\varphi$ Year Dummies $+\theta$ Industry Dummies $+\varepsilon_{i t}$

The sample includes Chinese RM firms, Chinese ADR firms, U.S. RM firms, and U.S. IPO firms. RM equals 1 for RM firms (i.e., Chinese RM or U.S. RM firms), and 0 otherwise. China equals 1 for Chinese firms (i.e., Chinese RM or Chinese ADR firms), and 0 otherwise. In Model (1), the dependent variable, Restatement $_{i t}$, is a dummy variable that equals 1 if the financial statement of firm $i$ in year $t$ is restated later, and 0 otherwise. In Model (2) [(3)], the dependent variable is Error ${ }_{i t}$ (Irregularity $_{i t}$ ), which equals 1 if the financial statement of firm $i$ in year $t$ is restated later and the restatement is classified as an error (irregularity), and 0 otherwise. The table reports the coefficient estimates, the corresponding z-statistics based on Wald Chi-square adjusted for firm- and yearlevel clustering (in parentheses), the number of observations, and the pseudo $\mathrm{R}^{2}$. All of the variables are winsorized at the 1 percent and 99 percent levels. Please see Appendix B for variable definitions.

(continued on next page)

One might argue that this result is not surprising, given the finding of Lang et al. (2006) that foreign firms listed in the U.S. have lower financial reporting quality than U.S. domestic firms. ${ }^{23}$ As discussed above, $\beta_{2}$ captures the difference in financial reporting quality between Chinese ADR and U.S. IPO firms. Also as reported in Table 3, Panel A, $\beta_{2}$ is insignificantly different from zero. This result differs from that of Lang et al. (2006), likely due to the use of different financial reporting quality

23 As discussed in Leuz (2006), the findings of Lang et al. (2006) indicate that cross-listing and bonding incentives improve financial reporting quality, but not to the extent that the financial reporting quality of cross-listed firms is fully comparable with that of U.S. firms. Leuz (2006) argues that this difference might be attributed to differential U.S. legal enforcement between the cross-listed firms and U.S. firms, and to the differences in firm-level reporting incentives. 
TABLE 3 (continued)

Panel B: Hypotheses Testing_All Restatements

\begin{tabular}{|c|c|c|c|}
\hline & $\begin{array}{l}\text { IPO/ADR Firms } \\
\text { (1) }\end{array}$ & $\begin{array}{l}\text { RM Firms } \\
(2)\end{array}$ & $\begin{array}{l}\text { RM Effect } \\
(2)-(1)\end{array}$ \\
\hline U.S. firms (a) & & $\begin{array}{l}0.593 \\
(1.60)\end{array}$ & $\begin{array}{l}\text { H1: For U.S. firms } \\
0.593 \\
(1.60)\end{array}$ \\
\hline $\begin{array}{l}\text { Chinese firms } \\
\text { (b) }\end{array}$ & $\begin{array}{l}-0.011 \\
(-0.02)\end{array}$ & $\begin{array}{l}2.057 * * *(=0.593-0.011+1.475) \\
(5.32)\end{array}$ & $\begin{array}{l}\mathrm{H} 2: \text { For Chinese firms } \\
2.068^{* * *} \\
(5.45)\end{array}$ \\
\hline $\begin{array}{l}\text { Weak country } \\
\text { Effect } \\
\text { (b) }- \text { (a) }\end{array}$ & $\begin{array}{l}\text { For IPO/ADR firms } \\
-0.011 \\
(-0.02)\end{array}$ & $\begin{array}{l}\text { H3: For RM firms } \\
1.464^{* * *} \\
(4.26)\end{array}$ & $\begin{array}{l}\text { Difference in differences } \\
1.475^{* * *} \\
(2.65)\end{array}$ \\
\hline
\end{tabular}

This panel summarizes the results for the test of $\mathrm{H} 1 \sim \mathrm{H} 3$ based on the analysis of the likelihood of all accounting restatements. For the coefficients presented in Panel A, the corresponding Z-statistics are presented in parentheses. For the sum of coefficients, Wald tests are conducted and the corresponding $\mathrm{Z}$-statistics are presented in parentheses.

measures. While we use the likelihood of restatements to capture financial reporting quality, Lang et al. (2006) use accrualbased measures. As reported in Srinivasan et al. (2015), foreign firms listed in U.S. exchanges have a lower frequency of restatements. To further examine whether the weak country effect alone explains these results, we investigate the interaction of the RM and weak country effects in explaining the financial reporting quality of Chinese RM firms, $\beta_{3}$. As reported in Panel A, the coefficient on the interaction term is significantly positive $(z=2.65)$. This result confirms that the combination of the RM and weak country effects contributes to the lower financial reporting quality of Chinese RM firms.

\section{Analysis of Errors and Accounting Irregularities}

The above analyses are based on all accounting restatements. To investigate whether the results are driven by errors, accounting irregularities, or both, we separately analyze the likelihood of errors and irregularities and report the results in Models (2) and (3), respectively, of Table 3, Panel A. Note that when we analyze the likelihood of errors, we drop the observations with accounting irregularities from the sample, as these cases are generally regarded as worse than errors. As is common in the literature, we keep observations with errors when analyzing the likelihood of irregularities, and the dependent variable, Irregularity, is set as 0 for these observations. (Excluding these observations from the analyses leads to the same results.) We find that Chinese firms, whether RM firms or ADR firms, have a higher likelihood of accounting errors than their counterparts. There is no evidence of an RM effect for China or for U.S. firms. In contrast, when we analyze the likelihood of accounting irregularities, we find that the coefficients on $R M$ and China are insignificantly different from zero, but the coefficient on the interaction term is significantly positive $(\mathrm{z}=2.58)$. Overall, we find that the results documented above are driven by the likelihood of accounting irregularities.

\section{Analysis of Accrual-Based Measures}

We use the following regression model to test the hypotheses based on accrual-based measures:

$$
F R Q_{i, t}=\alpha+\beta_{1} R M_{i t}+\beta_{2} \text { China }_{i t}+\beta_{3} R M_{i t} \times \text { China }_{i t}+\gamma \text { Controls }_{i, t}+\delta \text { Year Dummies }+\theta \text { Industry Dummies }+\varepsilon_{i, t}
$$

The dependent variable, $F R Q$, is one of the following variables: the absolute value of discretionary accruals $(|D A|)$, the absolute value of working capital accruals $(|D D|)$, the absolute value of discretionary revenue $(|D R|)$, the natural $\operatorname{logarithm}$ of the absolute value of the ratio of accruals to operating cash flows $(\ln |A C C R / O C F|)$, or the common factor. Higher variable values 
imply lower financial reporting quality. The model specification and the interpretation of the coefficients are the same as with Equation (1).

Panel A of Table 4 reports the regression results. The coefficient on $R M$ is insignificant, indicating that the RM effect itself does not lead to lower financial reporting quality for U.S. firms. The coefficient on China is significantly positive for the cases of $|D D|$ and the common factor, implying that Chinese ADR firms have lower financial reporting quality than U.S. IPO firms, as is consistent with the findings in Lang et al. (2006). More importantly, the coefficient on the interaction term is significantly positive in all specifications with the exception of $\ln |A C C R / O C F|$. As summarized in Panel B of Table 4, the inferences are the same as those based on the likelihood of accounting restatements.

Overall, the results based on accrual-based measures are consistent with those based on the likelihood of restatements. The lower financial reporting quality of Chinese RM firms is driven by a combination of the RM and the weak country effects.

\section{CHINESE RM VERSUS ADR FIRMS: BONDING INCENTIVES AND CORPORATE GOVERNANCE}

The results reported above indicate that Chinese RM firms have lower financial reporting quality than other firms, and that this is due to a combination of both the RM and the weak country effects. The RM effect by itself does not explain the poor financial reporting quality, because U.S. RM firms have similar financial reporting quality to that of U.S. IPO firms. The weak country effect alone does not explain the results either. Otherwise, Chinese RM firms would not have lower financial reporting quality than Chinese ADR firms. Given that Chinese RM and Chinese ADR firms are subject to the same weak legal enforcement and legal protection, it is important to understand why Chinese RM firms have weaker financial reporting quality. We hypothesize in $\mathrm{H} 4 \mathrm{a}$ and $\mathrm{H} 4 \mathrm{~b}$ that Chinese RM firms have weaker bonding incentives, and that the less scrutinized RM process provides these firms with a means to access the U.S. capital markets. In this section, we first investigate whether bonding incentives are indeed weaker for Chinese RM firms than for Chinese ADR firms, and then we examine whether the RM firms have poorer corporate governance than Chinese ADRs.

\section{Test of H4a: Is the Bonding Incentive Weaker for Chinese RM Firms?}

Lel and Miller (2008) argue that if the bonding to more stringent disclosure and reporting requirements is effective, then the corporate governance of cross-listed firms should improve. Research on CEO turnover (i.e., Shleifer and Vishny 1997) demonstrates that one outcome of effective corporate governance is the replacement of poorly performing CEOs. Building on this line of research, Lel and Miller (2008) use CEO turnover-performance sensitivity to capture the outcomes of corporate governance. They find that the CEO turnover-performance sensitivity is higher for cross-listed firms than for non-cross-listed firms, and that this effect is more pronounced when bonding is more effective. Thus, it follows that if Chinese RM firms have weaker bonding incentives and their bonding is less effective, then these firms should have lower CEO turnover-performance sensitivity than Chinese ADR firms. ${ }^{24}$ Following Lel and Miller (2008), we use the following regression to test this prediction:

$$
\begin{aligned}
\operatorname{Pr}\left(\text { CEO_Turnover }_{i t}\right)= & \alpha+\beta_{1} \text { PER }_{i, t-1}+\beta_{2} \text { CRM }_{i}+\beta_{3} \text { PER }_{i, t-1} \times \text { CRM }_{i}+\gamma \text { Controls }_{i, t}+\varphi \text { Year Dummies } \\
& +\lambda \text { Industry Dummies }+\varepsilon_{i t}
\end{aligned}
$$

CEO_Turnover ${ }_{i t}$ is a binary variable that equals 1 if the CEO of firm $i$ is replaced in year $t$. Following Lel and Miller (2008) and other studies on CEO turnover, we use two measures to capture firm performance (PER). The first measure is ROA, which is the earnings before interest and taxes divided by total assets. The second measure is industry-adjusted stock returns. We use the lagged performance measure to avoid overlapping the replaced CEO's performance with that of the new CEO. As CEO turnover-performance sensitivity is negative, we expect a positive coefficient on the interaction term if Chinese RM firms have weaker bonding incentives. We control for firm size, industry and year fixed effects (as in Lel and Miller [2008]), and for the control variables included in Equation (1), with the exception of ROE. ROE is not included because the model already includes the performance measure.

We hand-collect CEO turnover data from the financial statements and the Audit Analytics database. Untabulated analyses indicate that the CEO turnover ratio is 8.92 percent for Chinese RM firms and 15.87 percent for Chinese ADR firms, and that this difference is significant at the 0.01 level.

Table 5 presents the regression results. As in Lel and Miller (2008), the probability of CEO turnover is negatively correlated with firm performance $(\mathrm{z}=-2.98$ and -22.66 , respectively, when performance is measured as $R O A$ and stock returns). More importantly, the probability of CEO turnover is less sensitive to firm performance for Chinese RM firms than for

\footnotetext{
${ }^{24}$ DeFond and Hung (2004) find that CEO turnover-performance sensitivity varies with country-specific factors such as the effectiveness of investor protection. To the extent that CEO turnover-performance sensitivity might not be a valid measure of bonding incentives for Chinese firms, we might not find results consistent with H4a.
} 
TABLE 4

Test of H1 $\sim \mathrm{H3}$

Analysis of Accrual-based Financial Reporting Quality Measures

Panel A: Regression Results

\begin{tabular}{|c|c|c|c|c|c|}
\hline & $|\boldsymbol{D A}|$ & $|D D|$ & $|\boldsymbol{D R}|$ & $\ln |A C C R / O C F|$ & $F R Q$ \\
\hline \multirow[t]{2}{*}{$R M$} & -0.008 & 0.006 & 0.001 & 0.041 & 0.053 \\
\hline & $(-0.55)$ & $(0.62)$ & $(0.11)$ & $(0.48)$ & $(0.70)$ \\
\hline \multirow[t]{2}{*}{ China } & 0.005 & $0.049 * * *$ & 0.014 & 0.096 & $0.204 * *$ \\
\hline & $(0.38)$ & $(4.60)$ & $(1.25)$ & $(1.11)$ & $(2.02)$ \\
\hline \multirow[t]{2}{*}{$R M \times$ China } & $0.044 * * *$ & $0.036^{*}$ & $0.042 * * *$ & 0.099 & $0.300 * *$ \\
\hline & $(2.69)$ & $(1.77)$ & $(3.53)$ & $(0.79)$ & $(2.41)$ \\
\hline \multirow[t]{2}{*}{$M / B$} & -0.000 & 0.000 & -0.000 & $-0.007 * *$ & 0.001 \\
\hline & $(-1.42)$ & $(0.21)$ & $(-0.71)$ & $(-2.57)$ & $(0.61)$ \\
\hline \multirow[t]{2}{*}{ Growth } & $0.062 * * *$ & $0.035 * * *$ & $0.036 * * *$ & $0.046^{* * *}$ & $0.362 * * *$ \\
\hline & $(9.82)$ & $(6.74)$ & $(5.25)$ & $(2.75)$ & $(9.40)$ \\
\hline \multirow[t]{2}{*}{$L E V$} & -0.004 & -0.001 & $0.022 *$ & $1.320 * * *$ & 0.109 \\
\hline & $(-0.21)$ & $(-0.05)$ & $(1.66)$ & $(8.02)$ & $(0.98)$ \\
\hline \multirow[t]{2}{*}{$R O E$} & $-0.062 * * *$ & $-0.011 * *$ & 0.007 & -0.000 & $-0.205^{* * *}$ \\
\hline & $(-6.32)$ & $(-1.97)$ & $(0.94)$ & $(-0.01)$ & $(-4.74)$ \\
\hline \multirow[t]{2}{*}{ Size } & $-0.013 * * *$ & $-0.011 * * *$ & $-0.007 * * *$ & -0.027 & $-0.080 * * *$ \\
\hline & $(-3.82)$ & $(-6.10)$ & $(-4.42)$ & $(-1.49)$ & $(-4.36)$ \\
\hline \multirow[t]{2}{*}{ Capital_Need } & 0.002 & 0.004 & -0.002 & $-0.074 *$ & 0.002 \\
\hline & $(0.24)$ & $(0.58)$ & $(-0.30)$ & $(-1.91)$ & $(0.06)$ \\
\hline \multirow[t]{2}{*}{ Loss } & $-0.065 * * *$ & $-0.050 * * *$ & -0.015 & $0.538 * * *$ & $-0.257 * * *$ \\
\hline & $(-4.65)$ & $(-6.69)$ & $(-1.58)$ & $(4.28)$ & $(-2.85)$ \\
\hline \multirow[t]{2}{*}{ Op_Cycle } & 0.008 & $0.008 * *$ & 0.004 & $-0.040 * * *$ & 0.033 \\
\hline & $(1.42)$ & $(2.27)$ & $(1.26)$ & $(-2.74)$ & $(1.28)$ \\
\hline \multirow[t]{2}{*}{ Inventory } & $0.062 * * *$ & $0.124 * * *$ & $0.054 *$ & $1.349 * * *$ & $0.753 * * *$ \\
\hline & $(3.84)$ & $(3.82)$ & $(1.71)$ & $(5.08)$ & $(4.33)$ \\
\hline Year effects & Yes & Yes & Yes & Yes & Yes \\
\hline Industry effects & Yes & Yes & Yes & Yes & Yes \\
\hline $\mathrm{n}$ & 1,806 & 1,736 & 1,836 & 1,776 & 1,730 \\
\hline Adjusted $\mathrm{R}^{2}$ & 0.401 & 0.307 & 0.314 & 0.198 & 0.432 \\
\hline
\end{tabular}

***,**,* Indicate statistical significance at the 1 percent, 5 percent, and 10 percent levels, respectively (two-tailed t-test).

This panel reports the results from regressing the financial reporting quality measures on the indicators for firm types and control variables:

$F R Q_{i, t}=\alpha+\beta_{1} R M_{i t}+\beta_{2}$ China $_{i t}+\beta_{3} R M_{i t} \times$ China $_{i t}+\gamma$ Controls $_{i, t}+\delta$ Year Dummies $+\theta$ Industry Dummies $+\varepsilon_{i, t}$

The sample includes Chinese RM firms, Chinese ADR firms, U.S. RM firms, and matched U.S. IPO firms. RM equals 1 for RM firms (i.e., Chinese RM or U.S. RM firms), and 0 otherwise. China equals 1 for Chinese firms (i.e., Chinese RM or Chinese ADR firms), and 0 otherwise. This table reports the coefficient estimates, $t$-values based on standard errors adjusted for firm- and year-level clustering (in parentheses), the number of observations, and the adjusted $\mathrm{R}^{2}$. All of the variables are winsorized at the 1 percent and 99 percent levels.

Please see Appendix B for variable definitions.

(continued on next page)

Chinese ADR firms. The coefficient on PER $\times C R M$ is significantly positive at the 0.05 level $(\mathrm{z}=2.04$ and 2.05, respectively). ${ }^{25}$ This result is consistent with $\mathrm{H} 4 \mathrm{a}$, that Chinese $\mathrm{RM}$ firms have weaker bonding incentives, i.e., lower incentives to improve corporate governance for signaling their intention to protect minority shareholder rights.

\section{Test of H4b: Corporate Governance of Chinese RM Firms versus Chinese ADR Firms}

In this section, we test $\mathrm{H} 4 \mathrm{~b}$ by examining whether the RM process attracts Chinese firms with weak bonding incentives, as exemplified by their corporate governance features. We first investigate the differences in corporate governance between

\footnotetext{
${ }^{25}$ A Wald test indicates that the net turnover-performance sensitivity for Chinese RM firms $(P E R+P E R \times C R M)$ is insignificantly different from zero ( $\mathrm{p}$ $=0.418$ and 0.875 , respectively).
} 
TABLE 4 (continued)

Panel B: Hypotheses Testing_FRQ

IPO/ADR Firms

(1)
RM Firms

(2)

\begin{tabular}{|l|l|l|}
\cline { 2 - 3 } \multicolumn{1}{c|}{ U.S. firms (a) } & $\begin{array}{l}0.053 \\
(0.70)\end{array}$ \\
\cline { 2 - 3 } Chinese firms (b) & $\begin{array}{l}0.204^{* *} \\
(2.02)\end{array}$ & $\begin{array}{l}0.557^{* * *}(=0.053+0.204+0.300) \\
(5.90)\end{array}$ \\
\cline { 2 - 3 } & &
\end{tabular}

Weak country For IPO/ADR firms

Effect $0.204 * *$

(b) - (a) (2.02)
H3: For RM firms

$0.504 * * *$

(4.02)
RM Effect

(2) $-(1)$

H1: For U.S. firms

0.053

$(0.70)$

$\mathrm{H} 2$ : For Chinese firms

$0.353 * * *$

(3.68)

Difference in differences

$0.300 * *$

(2.41)

This panel summarizes the results for the test of $\mathrm{H} 1 \sim \mathrm{H} 3$ based on the analysis of the common factor of accrual-based financial reporting quality measures, $F R Q$. For the coefficients presented in Panel A, the corresponding t-statistics are presented in parentheses. For the sum of coefficients, F-tests are conducted and the corresponding t-statistics are presented in parentheses.

Chinese RM and ADR firms, and then examine the extent to which these factors explain their differences in financial reporting quality.

We hand-collect all of the required information from 10-Ks, 20-Fs, and proxy statements filed by Chinese firms, including the data on insider ownership (holdings by the officers and directors), the existence of foreign blockholders (non-Chinese owners with 10 percent or more of the shares), board characteristics (board size, board independence, and whether the CEO is the chairman), whether the CEO is the founder of the firm, and whether the CEO receives option grants. ${ }^{26}$

Panel A of Table 6 reports descriptive statistics on these variables separately for Chinese RM and Chinese ADR firms, and the p-values for the differences in means and medians. We find that compared to Chinese ADR firms, Chinese RM firms have higher insider ownership, fewer foreign blockholders, smaller and less independent boards, higher likelihood of having the CEO as the chairman, and lower likelihood of having a founder CEO or of granting the CEO option-based compensation.

To ensure that these results are not driven by other firm characteristics, Panel B of Table 6 reports the results from regressing the indicator variable for Chinese RM firms (versus Chinese ADR firms) on the above-described corporate governance variables. As reported in Column (1), we find results similar to those in the univariate analysis, except that board independence is not significantly associated with the likelihood of choosing the RM method for listing. In Column (2), we further control for firm fundamental characteristics. The results remain the same except that Chinese RM firms appear to have higher board independence. ${ }^{27}$

Overall, the results are consistent with H4b that corporate governance in Chinese RM firms is weaker than that in Chinese ADR firms.

Next, we use a two-stage process to examine whether the differences in corporate governance features lead to differences in financial reporting quality. In the first stage, we predict the probability of a Chinese firm being an RM firm using the specification as in Column (2) of Table 6, Panel B. In the second stage, we use the predicted value of CRM (CRM_P) and the residual $\left(C R M_{-} R\right)$, as generated from the first-stage model, to explain the financial reporting quality of Chinese RM and ADR firms:

$$
F R Q_{i, t}=\alpha+\beta_{1} C R M \_P_{i, t}+\beta_{2} C R M \_R_{i, t}+\gamma \text { Controls }_{i, t}+\delta \text { Year Dummies }+\theta \text { Industry Dummies }+\varepsilon_{i, t}
$$

The dependent variable, $F R Q$, is the likelihood of accounting restatements or the common factor generated from the individual accrual-based measures. If the weak corporate governance of Chinese RM firms leads to lower financial reporting quality, then

\footnotetext{
${ }^{26}$ Leuz, Nanda, and Wysocki (2003) argue that higher insider ownership weakens firm governance, and Siegel (2005) argues that having a large foreign shareholder can improve the governance of a firm.

27 This difference might reflect the different regulatory requirements concerning board independence for Chinese RM firms and Chinese ADR firms. As discussed above, Chinese ADR firms are exempt from some regulatory requirements related to disclosure and governance.
} 
TABLE 5

\section{Sensitivity of CEO Turnover to Firm Performance among U.S.-Listed Chinese Firms}

(1)

Performance Measure:
ROA

PER

CRM

$P E R \times C R M$

$M / B$

Growth

$L E V$

Size

Capital_Need

Loss

Op_Cycle

Inventory

Industry fixed effect Year fixed effect

n

Pseudo $\mathrm{R}^{2}$
$-4.377 * * *$

$(-2.98)$

$-1.537 * * *$

$(-7.87)$

$2.782 * *$

(2.04)

0.009

(1.63)

$-1.051^{* * *}$

$(-3.12)$

$-1.107 * *$

$(-2.10)$

$0.119 * *$

(2.51)

0.270

(1.33)

$-0.230$

$(-0.67)$

$-0.187 * *$

$(-2.08)$

$-3.137 *$

$(-1.88)$

Yes

Yes

1,083

$25.4 \%$
(2)

Performance Measure: Industry Adjusted Stock Returns

$-0.389 * * *$

$(-22.66)$

$-2.692 * * *$

$(-5.32)$

$0.368 * *$

(2.05)

$-0.038$

$(-1.31)$

$-1.886^{* * *}$

$(-3.11)$

$-0.663$

$(-0.50)$

0.115

$(1.46)$

0.099

$(0.35)$

$0.237 * *$

(2.30)

$-1.165^{*}$

$(-1.70)$

$-5.069$

$(-1.62)$

Yes

Yes

619

$32.9 \%$

***,**,* Indicate statistical significance at the 1 percent, 5 percent, and 10 percent levels, respectively.

This table reports the logit regression of the probability of CEO turnover:

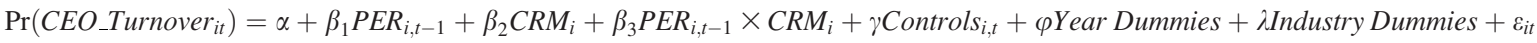

CEO_Turnover $i t$ is an indicator for CEO turnover that equals 1 if there is a change in CEO in year $t$, and 0 otherwise. PER is measured in two alternative ways: (1) the natural logarithm of 1 plus the ratio of earnings before interest and tax over total assets, and (2) the natural logarithm of 1 plus industryadjusted stock return. This table reports the coefficient estimates, the corresponding z-statistics based on the Wald Chi-square adjusted for firm- and yearlevel clustering (in parentheses), the number of observations, and the pseudo $\mathrm{R}^{2}$. All of the variables are winsorized at the 1 percent and 99 percent levels. Please see Appendix B for the definitions of other variables.

$C R M \_P$ should be negatively correlated with financial reporting quality, resulting in a positive coefficient on $C R M \_P$. The coefficient on the residual value of $C R M\left(C R M \_R\right)$ captures the effect of other unidentified differences between Chinese RM and ADR firms in terms of financial reporting quality.

Table 7 reports the regression results. Panel A for the analysis of accounting restatements, and Panel B for the analysis of the common factor of the accrual-based financial reporting quality measures. As the sample size is smaller due to additional data requirements, we first investigate whether Chinese RM firms have lower financial reporting quality (as documented above), and we obtain quantitatively similar results. Column (2) of each panel reports the results from Equation (4). We find that the coefficient on $C R M \_P$ is significantly positive. This result indicates that the corporate governance decisions made by Chinese firms are strongly correlated with financial reporting quality. The coefficient on $C R M \_R$ in each of the panels is also significantly positive, although it is smaller than that on CRM_P. ${ }^{28}$

\footnotetext{
28 An untabulated analysis indicates that the coefficient on $C R M_{-} P$ is significantly larger than that on $C R M_{-} R$. The p-value of the Wald test is 0.09 (in Panel A of Table 7), and that of the F-test is 0.01 (in Panel B). Note that our focus is the coefficient on CRM_P, not the coefficient on CRM_R or the difference in coefficient between $C R M_{-} P$ and $C R M_{-} R$.
} 
TABLE 6

Corporate Governance and Financial Reporting Quality of U.S.-Listed Chinese Firms

Panel A: Descriptive Statistics on Corporate Governance Characteristics of Chinese RM Firms and Chinese ADR Firms

\begin{tabular}{|c|c|c|c|c|c|c|c|c|}
\hline & \multicolumn{3}{|c|}{ Chinese RM Firms } & \multicolumn{3}{|c|}{ Chinese ADR Firms } & \multicolumn{2}{|c|}{$\begin{array}{l}\text { p-value for t-test } \\
\text { and Wilcoxon } z \text {-test } \\
\text { for Differences in }\end{array}$} \\
\hline & Mean & Median & Std. & Mean & Median & Std. & Mean & Median \\
\hline Inside_Own & 0.38 & 0.39 & 0.25 & 0.21 & 0.17 & 0.22 & 0.001 & 0.001 \\
\hline Foreign_Own & 0.05 & 0.00 & 0.10 & 0.10 & 0.00 & 0.15 & 0.001 & 0.001 \\
\hline BD_Size & 5.02 & 5.00 & 1.94 & 7.76 & 7.00 & 2.51 & 0.001 & 0.001 \\
\hline$B D$ Independence & 0.49 & 0.60 & 0.27 & 0.59 & 0.60 & 0.16 & 0.001 & 0.001 \\
\hline CEO_Chair & 0.82 & 1.00 & 0.48 & 0.60 & 1.00 & 0.49 & 0.001 & 0.001 \\
\hline Founder_CEO & 0.47 & 0.00 & 0.57 & 0.51 & 1.00 & 0.50 & 0.128 & 0.048 \\
\hline CEO_Option & 0.36 & 0.00 & 0.48 & 0.79 & 1.00 & 0.41 & 0.001 & 0.001 \\
\hline
\end{tabular}

This panel reports descriptive statistics on the corporate governance characteristics of Chinese RM firms and Chinese ADR firms, and the p-value for the difference between these two samples. There are 686 observations from Chinese RM firms and 745 from Chinese ADR firms. (The sample for Panel B is smaller due to additional data requirements.)

Panel B: Corporate Governance and the Listing Choices of Chinese Firms

\begin{tabular}{|c|c|c|}
\hline & (1) & (2) \\
\hline Inside_Own & $\begin{array}{l}2.328 * * * \\
(7.15)\end{array}$ & $\begin{array}{l}1.570^{* * * *} \\
(3.21)\end{array}$ \\
\hline Foreign_Own & $\begin{array}{l}-3.065^{* * *} \\
(-5.31)\end{array}$ & $\begin{array}{l}-2.691 * * * \\
(-2.95)\end{array}$ \\
\hline BD_Size & $\begin{array}{l}-0.553 * * * \\
(-13.11)\end{array}$ & $\begin{array}{l}-0.264^{* * * *} \\
(-3.61)\end{array}$ \\
\hline BD_Independence & $\begin{array}{c}0.694 \\
(1.50)\end{array}$ & $\begin{array}{l}2.971 \text { *** } \\
(3.32)\end{array}$ \\
\hline CEO_Chair & $\begin{array}{l}0.986 * * * \\
(6.00)\end{array}$ & $\begin{array}{l}1.220^{* * *} \\
(4.54)\end{array}$ \\
\hline Founder_CEO & $\begin{array}{l}-1.186^{* * *} \\
(-7.61)\end{array}$ & $\begin{array}{l}-1.208 * * * \\
(-5.05)\end{array}$ \\
\hline CEO_Option & $\begin{array}{l}-1.733 * * * \\
(-10.53)\end{array}$ & $\begin{array}{l}-1.453 * * * \\
(-5.82)\end{array}$ \\
\hline$M / B$ & & $\begin{array}{l}-0.026 \\
(-0.96)\end{array}$ \\
\hline Growth & & $\begin{array}{r}0.058 \\
(0.57)\end{array}$ \\
\hline$R O E$ & & $\begin{array}{l}0.937 * * \\
(2.32)\end{array}$ \\
\hline Size & & $\begin{array}{l}-1.157 * * * \\
(-9.53)\end{array}$ \\
\hline$L E V$ & & $\begin{array}{l}4.536^{* * * *} \\
(5.48)\end{array}$ \\
\hline Capital_Need & & $\begin{array}{c}0.132 \\
(0.90)\end{array}$ \\
\hline Op_Cycle & & $\begin{array}{l}-0.133 \\
(-0.72)\end{array}$ \\
\hline Inventory & & $\begin{array}{l}3.567 * * * \\
(2.88)\end{array}$ \\
\hline Loss & & $\begin{array}{l}-0.734 \\
(-1.20)\end{array}$ \\
\hline
\end{tabular}

(continued on next page) 
TABLE 6 (continued)

\begin{tabular}{lcc} 
& $\mathbf{( 1 )}$ & $\mathbf{( 2 )}$ \\
\cline { 2 - 3 } Constant & $3.684 * * *$ & $5.191 * * *$ \\
& $(8.18)$ & $(5.15)$ \\
$\mathrm{n}$ & 1,431 & 1,002 \\
Pseudo $\mathrm{R}^{2}$ & $37.2 \%$ & $56.1 \%$
\end{tabular}

***,**,* Indicate statistical significance at the 1 percent, 5 percent, and 10 percent levels, respectively.

This panel reports the logit regression of the indicator variable for Chinese RM firms (versus Chinese ADR firms) on corporate governance characteristics and firm fundamentals. The dependent variable, $C R M$, equals 1 for Chinese RM firms, and 0 for Chinese ADR firms. Please see below for the definitions of corporate governance variables and Appendix B for the definitions of firm characteristics. The table reports the coefficient estimates, the corresponding z-statistics based on the Wald Chi-square adjusted for firm- and year-level clustering (in parentheses), the number of observations, and the pseudo $\mathrm{R}^{2}$. All of the variables are winsorized at the 1 percent and 99 percent levels.

Variable Definitions:

Inside_Own $=$ the percentage of ownership by officers and directors;

Foreign $O w n=$ a dummy variable that equals 1 if the firm has at least one large foreign owner (ownership greater than 10 percent);

$B D$ Size $=$ the size of the board;

$B D^{-}$Independence $=$the percentage of outside directors on the board;

$C E \bar{O} \_$Chair $=$a dummy variable that equals 1 when the $\mathrm{CEO}$ is also the chairman of the firm;

Founder_CEO = a dummy variable that equals 1 when the CEO is the founder; and

CEO_Option $=$ a dummy variable that equals 1 if the CEO receives option grants in the year.

In summary, the results presented in this section are consistent with the notion that Chinese RM firms have weaker bonding incentives and are less willing than Chinese ADR firms to improve their corporate governance to signal an intention to protect shareholder rights. These factors are correlated with a firm's decision to choose the RM approach for accessing U.S. capital markets, and these factors partially explain the lower financial reporting quality of Chinese RM firms.

We clarify that we consider only one manifestation of weak corporate governance-poor financial reporting quality. Corporate governance also affects other corporate decisions (e.g., investments) and it influences firm value. As such, the results presented above do not imply that Chinese RM firms have suboptimal corporate governance. More importantly, determining whether Chinese RM firms have suboptimal corporate governance is beyond the scope of this paper, and this issue is left for future research.

\section{Change in Financial Reporting Quality after the Listing Process}

To provide further insight on whether the self-selection argument discussed above is the primary driver for the lower financial reporting quality of Chinese RM firms (relative to Chinese ADR firms), we examine changes in financial reporting quality after the listing process for Chinese RM firms. Due to the strict requirements for ongoing reporting, one would expect that the financial reporting quality should improve for Chinese RM firms after the listing process. However, the lower levels of investor protection in China and the difficulties that the SEC has in disciplining listed foreign firms both suggest that RM firms might not experience an improvement in financial reporting quality. Therefore, whether Chinese RM firms show improvements in financial reporting quality after their listings is an empirical question. The untabulated results indicate that Chinese RM firms have similar or better financial reporting quality after the RM process, depending on the measure used to capture financial reporting quality. ${ }^{29}$ However, despite this improvement after the RM process, the quality of financial reporting is still lower than that of Chinese ADR firms. Thus, this analysis further supports our main inference: Chinese firms that have weaker bonding incentives and lower financial reporting quality commonly choose to use the less scrutinized RM process to obtain access to U.S. capital markets, resulting in lower financial reporting quality.

Although these additional analyses provide results consistent with the self-selection argument based on bonding incentives, we would caution the readers that these change analyses are based on a small sample.

\footnotetext{
${ }^{29}$ For this analysis, we collect financial statement information from Super 8-Ks for the sample of 287 Chinese RM firms. More than half (167) of these firms do not have meaningful financial statements in their Super 8-K filings. We then require the firms to have non-negative common shareholders' equity, non-zero sales, assets of $\$ 1$ million dollars or more, and at least one year of data. These requirements result in a total of 186 firm-years with basic financial statement data (i.e., equity, assets, and sales) from 89 firms. By further requiring the firms to have data on the control variables and dependent variables, we are left with 22 firm-years from 21 Chinese RM firms. We then combine these observations with the post-RM observations of these firms to conduct the analysis.
} 
TABLE 7

\section{Corporate Governance and Financial Reporting Quality of U.S.-Listed Chinese Firms}

\section{Panel A: Analysis of Accounting Restatements}

\begin{tabular}{|c|c|c|}
\hline & (1) & (2) \\
\hline CRM & $\begin{array}{l}1.924 * * * \\
(5.01)\end{array}$ & \\
\hline CRM_P & & $\begin{array}{l}1.493 * * * \\
(2.71)\end{array}$ \\
\hline$C R M \_R$ & & $\begin{array}{l}0.646^{* * * *} \\
(4.65)\end{array}$ \\
\hline$M / B$ & $\begin{array}{c}-0.077 \\
(-1.51)\end{array}$ & $\begin{array}{l}-0.076 \\
(-1.55)\end{array}$ \\
\hline Growth & $\begin{array}{r}0.084 \\
(0.96)\end{array}$ & $\begin{array}{r}0.091 \\
(1.05)\end{array}$ \\
\hline$L E V$ & $\begin{array}{c}0.168 \\
(0.21)\end{array}$ & $\begin{array}{c}0.265 \\
(0.33)\end{array}$ \\
\hline$R O E$ & $\begin{array}{c}0.144 \\
(0.41)\end{array}$ & $\begin{array}{r}0.162 \\
(0.46)\end{array}$ \\
\hline Size & $\begin{array}{l}-0.096 \\
(-1.01)\end{array}$ & $\begin{array}{l}-0.125 \\
(-1.23)\end{array}$ \\
\hline Capital_Need & $\begin{array}{l}0.312^{* *} \\
(2.35)\end{array}$ & $\begin{array}{l}0.288^{* *} \\
(2.17)\end{array}$ \\
\hline Loss & $\begin{array}{c}0.890 \\
(1.50)\end{array}$ & $\begin{array}{c}0.813 \\
(1.40)\end{array}$ \\
\hline Op_Cycle & $\begin{array}{c}0.038 \\
(0.28)\end{array}$ & $\begin{array}{c}0.034 \\
(0.25)\end{array}$ \\
\hline Inventory & $\begin{array}{l}-0.962 \\
(-0.69)\end{array}$ & $\begin{array}{l}-0.805 \\
(-0.58)\end{array}$ \\
\hline Year effects & Yes & Yes \\
\hline Industry effects & Yes & Yes \\
\hline $\mathrm{n}$ & 1,002 & 1,002 \\
\hline Adjusted $\mathrm{R}^{2}$ & $20.3 \%$ & $19.4 \%$ \\
\hline
\end{tabular}

***,**,* Indicate statistical significance at the 1 percent, 5 percent, and 10 percent levels, respectively.

This panel reports the logit regression of the probability of accounting restatements. Column (1) reports the logit regression results based on the sample of U.S.-listed Chinese firms with required data on corporate governance, financial reporting quality, and control variables:

Prob $\left(\right.$ Restatement $\left._{i t}\right)=\alpha+\beta C R M_{i t}+\gamma$ Controls $_{i t-1}+\varphi$ Year Dummies $+\theta$ Industry Dummies $+\varepsilon_{i t}$

Column (2) reports the results when replacing $C R M$ with the fitted value $\left(C R M P_{-}\right)$and the corresponding residual value $\left(C R M R_{-}\right)$as estimated from the Chinese RM and Chinese ADR selection model, as reported in Column (2) of Table 6, Panel B:

$$
\operatorname{Prob}\left(\text { Restatement }_{i t}\right)=\alpha+\beta_{1} C R \Omega_{-} P_{i t}+\beta_{2} C R M R_{i t}+\gamma \text { Controls }_{i t-1}+\varphi \text { Year Dummies }+\theta \text { Industry Dummies }+\varepsilon_{i t}
$$

The dependent variable, Restatement $t_{i}$, is a dummy variable that equals 1 if the financial statement of firm $i$ in year $t$ is restated later, and 0 otherwise. The table reports the coefficient estimates, the corresponding Z-statistics based on the Wald Chi-square adjusted for firm- and year-level clustering (in parentheses), the number of observations, and the pseudo $\mathrm{R}^{2}$. All of the variables are winsorized at the 1 percent and 99 percent levels.

Please see Appendix B for variable definitions.

\section{Panel B: Analysis of Accrual-Based Financial Reporting Quality Measures}

\begin{tabular}{lcc} 
& \multicolumn{1}{c}{$(\mathbf{1})$} & $(\mathbf{2})$ \\
\cline { 2 - 3 }$C R M$ & $0.197^{* *}$ & \\
CRM_P & $(2.25)$ & $0.270^{*}$ \\
& & $(1.84)$ \\
$C R M_{-} R$ & & $0.078^{* *}$ \\
$M / B$ & & $(2.41)$ \\
& & 0.005 \\
& 0.004 & $(1.57)$
\end{tabular}

(continued on next page) 
TABLE 7 (continued)

\begin{tabular}{lcc} 
& $(\mathbf{1})$ & $(\mathbf{2})$ \\
\cline { 2 - 3 } Growth & $0.449^{* * *}$ & $0.422^{* * *}$ \\
LEV & $(11.83)$ & $(10.62)$ \\
& $0.370^{*}$ & 0.287 \\
ROE & $(1.87)$ & $(1.34)$ \\
& 0.006 & 0.036 \\
Size & $(0.08)$ & $(0.42)$ \\
& $-0.083^{* * *}$ & $-0.072^{* * *}$ \\
Capital_Need & $(-3.93)$ & $(-3.07)$ \\
& 0.000 & -0.004 \\
Loss & $(0.01)$ & $(-0.11)$ \\
& $-0.357^{*}$ & -0.311 \\
Op_Cycle & $(-1.93)$ & $(-1.63)$ \\
Inventory & $0.139^{* * *}$ & $0.132 * * *$ \\
& $(2.82)$ & $(2.81)$ \\
Year effects & $0.940^{* * *}$ & $1.005^{* * *}$ \\
Industry effects & $(2.61)$ & $(2.78)$ \\
n & Yes & Yes \\
Adjusted R ${ }^{2}$ & Yes & Yes \\
& 948 & 948
\end{tabular}

***,**,* Indicate statistical significance at the 1 percent, 5 percent, and 10 percent levels, respectively (two-tailed t-tests).

Column (1) reports the regression results based on the sample of U.S.-listed Chinese firms with the required data on corporate governance, financial reporting quality, and control variables: $F R Q_{i t}=\alpha+\beta_{1} C R M+\beta_{3}$ Controls $_{i t}+\varepsilon_{i t}$

Column (2) reports results from regressing the financial reporting quality measures on the fitted value $\left(C R M_{-} P\right)$ and the corresponding residual value $\left(C R M_{-} R\right)$ as estimated from the Chinese RM and Chinese ADR selection model, as reported in Column (2) of Table 6, Panel $\mathrm{B}: F R Q_{i t}=\alpha+\beta_{1} C R M$ $P_{i t}+\beta_{2} C R M R_{i t}+\beta_{3}$ Controls $_{i t}+\varepsilon_{i t}$

The panel reports the coefficient estimates, t-statistics adjusted for firm- and year-level clustering (in brackets), the number of observations, and the adjusted $\mathrm{R}^{2}$. All of the variables are winsorized at the 1 percent and 99 percent levels.

Please see Appendix B for the definitions of other variables.

\section{THE MARKET'S PERCEPTION OF CHINESE RM FIRMS' FINANCIAL REPORTING QUALITY}

The results so far indicate that Chinese RM firms have lower financial reporting quality due to a combination of the RM effect and the weak country effect. It is natural to ask whether the markets recognize Chinese RM firms' low financial reporting quality. We explore this issue in this section.

One commonly used proxy for the capital markets' perception of financial reporting quality is the earnings response coefficient (ERC) (e.g., Wilson 2008; Chen, Cheng, and Lo 2014). In this section, we examine whether the ERC differs between Chinese RM firms and other firms. Column (1) of Table 8 reports the results based on quarterly earnings announcements. Using the standard research design, we find that Chinese RM firms have ERCs similar to those of matched U.S. IPO firms, Chinese ADR firms, and U.S. RM firms. These results indicate that the market does not recognize the low financial reporting quality of Chinese RM firms at the times when their earnings are announced.

In case the market reacts to the poor earnings quality of Chinese RM firms throughout the year, Column (2) of Table 8 reports the annual regression results, based on the regression of annual returns on earnings changes and levels. We find that the market reacts less positively to the earnings changes of Chinese RM firms than to those of other firms. In other words, the earnings changes of Chinese RM firms are viewed as less credible than those of other firms.

Overall, although we find that the market does not recognize the low financial reporting quality of Chinese RM firms at the times that quarterly earnings are announced, the market does react less positively to the changes in the earnings of Chinese RM firms throughout the year.

\section{CONCLUSION}

In this paper, we find that Chinese RM firms have lower financial reporting quality (proxied for by the likelihood of accounting restatements and four accrual-based measures) than matched U.S. IPO firms, U.S. RM firms, or Chinese ADR firms. However, we do not find any difference in financial reporting quality between U.S. RM firms and matched U.S. IPO firms. 


\section{TABLE 8}

\section{Analysis of the Earnings Response Coefficient}

\begin{tabular}{|c|c|c|}
\hline & $\begin{array}{c}\text { Quarterly Regression } \\
\text { Model (1) }\end{array}$ & $\begin{array}{c}\text { Annual Regression } \\
\text { Model (2) }\end{array}$ \\
\hline$R M$ & $\begin{array}{c}0.021 \\
(1.60)\end{array}$ & $\begin{array}{l}-0.060 \\
(-0.93)\end{array}$ \\
\hline China & $\begin{array}{l}-0.004 \\
(-0.76)\end{array}$ & $\begin{array}{l}0.177 * * * \\
(2.69)\end{array}$ \\
\hline$R M \times$ China & $\begin{array}{l}-0.022 * \\
(-1.93)\end{array}$ & $\begin{array}{c}0.176 \\
(1.38)\end{array}$ \\
\hline$U E$ & $\begin{array}{l}0.127 * * * \\
(6.19)\end{array}$ & $\begin{array}{l}0.176^{* * *} \\
(4.21)\end{array}$ \\
\hline$U E \times R M$ & $\begin{array}{l}-0.013 \\
(-1.10)\end{array}$ & $\begin{array}{l}-0.025 \\
(-0.94)\end{array}$ \\
\hline$U E \times$ China & $\begin{array}{c}0.026 \\
(0.84)\end{array}$ & $\begin{array}{r}0.103 \\
(0.97)\end{array}$ \\
\hline$U E \times R M \times$ China & $\begin{array}{l}-0.028 \\
(-0.99)\end{array}$ & $\begin{array}{l}-0.390 * * * \\
(-3.40)\end{array}$ \\
\hline E & & $\begin{array}{l}0.246^{* * *} \\
(2.77)\end{array}$ \\
\hline$E \times R M$ & & $\begin{array}{c}0.123 \\
(1.41)\end{array}$ \\
\hline$E \times$ China & & $\begin{array}{l}-0.096 * * * \\
(-4.40)\end{array}$ \\
\hline$E \times R M \times$ China & & $\begin{array}{c}0.029 \\
(0.20)\end{array}$ \\
\hline Control variables & Yes & Yes \\
\hline Control variables $\times U E$ & Yes & Yes \\
\hline Control variables $\times E$ & & Yes \\
\hline Year or quarter fixed effect & Yes & Yes \\
\hline Industry fixed effect & Yes & Yes \\
\hline $\mathrm{n}$ & 3,197 & 991 \\
\hline Adjusted $\mathrm{R}^{2}$ & $3.9 \%$ & $12.6 \%$ \\
\hline
\end{tabular}

$* * *, * *, *$ Indicate statistical significance at the 1 percent, 5 percent, and 10 percent levels, respectively (two-tailed t-test).

This table reports results from the regressions of unexpected return (UR) over unexpected earnings at the quarterly level (Model (1)) and at the annual level (Model (2)). In Model (1), the dependent variable, $U R_{i q}$, is the cumulative abnormal returns in the three-day window around the earnings announcement date for firm $i$ in quarter $q$, where the abnormal return is defined as the firm's return less the CRSP value-weighted market return. $U E_{i q}$. is firm $i$ 's unexpected quarterly earnings in quarter $q$, which is measured as the seasonal change in earnings scaled by stock price at the end of the fiscal quarter $q$. In Model (2), the dependent variable, $U R_{i t}$, is the cumulative abnormal returns one day after year $t-1$ 's earnings announcement until one day after year $t$ 's earnings announcement, where the abnormal return is defined as the firm's return less the CRSP value-weighted market return. $U E_{i t}\left(E_{i t}\right)$ is firm $i$ 's change in (level of) earnings in year $t$, scaled by stock price one day after earnings announcement for fiscal year $t-1$. Control variables include $M / B$, Size, and Loss. Please see Appendix B for the definition of control variables, except that the control variables are measured at the quarterly level for Model (1). The table reports the coefficient estimates, the corresponding t-statistics based on standard errors adjusted for firm- and quarter- or year-level clustering, the number of observations, and adjusted $\mathrm{R}^{2}$. All of the variables are winsorized at the 1 percent and 99 percent levels.

These results indicate that the lower financial reporting quality of Chinese RM firms results from the joint effects of using the RM approach and the weak legal enforcement over Chinese firms. Additional analyses indicate that compared with Chinese ADR firms, Chinese RM firms have lower CEO turnover-performance sensitivity (a measure of the strength of the bonding incentive). These RM firms also exhibit poorer corporate governance, which partly explains their low quality of financial reporting.

This paper extends the literature by shedding light on why Chinese RM firms have low financial reporting quality. Our results indicate that the RM process provides those Chinese firms that have weak bonding incentives and poor governance with the opportunity to access the U.S. capital markets, resulting in the poor financial reporting quality of Chinese RM firms. These results should be of interest to regulators who consider the rules for RMs and to investors who trade these firms' shares. 


\section{REFERENCES}

Adjei, F., K. B. Cyree, and M. M. Walker. 2008. The determinants and survival of reverse mergers versus IPOs. Journal of Economics and Finance 32 (2): 176-194.

Aguilar, L. A. 2011. Facilitating real capital formation. Speech given at the SEC Council of Institutional Investors Spring Meeting. Washington, DC, April 4. Available at: http://www.sec.gov/news/speech/2011/spch040411laa.htm

Ang, J. S., Z. Jiang, and C. Wu. 2016. Good apples, bad apples: Sorting among Chinese companies traded in the U.S. Journal of Business Ethics 134 (4): 611-629.

Bailey, W., G. A. Karolyi, and C. Salva. 2006. The economic consequences of increased disclosure: Evidence from international crosslistings. Journal of Financial Economics 81 (1): 175-213.

Ball, R., A. Robin, and J. S. Wu. 2003. Incentives versus standards: Properties of accounting income in four East Asian countries. Journal of Accounting and Economics 36 (1/3): 235-270.

Ball, R., and L. Shivakumar. 2006. The role of accruals in asymmetrically timely gain and loss recognition. Journal of Accounting Research 44 (2): 207-242.

Burgstahler, D. C., L. Hail, and C. Leuz. 2006. The importance of reporting incentives: Earnings management in European private and public firms. The Accounting Review 81 (5): 983-1016.

Carcello, J. V., B. T. Carver, C. S. Lennox, and T. L. Neal. 2014. When Bonding Fails: Audit Firm Oversight of U.S.-Listed Chinese Companies. Working paper, The University of Tennessee.

Chen, X., Q. Cheng, and A. K. Lo. 2014. Is the decline in the information content of earnings following restatements short-lived? The Accounting Review 89 (1): 177-207.

Cheng, B., S. Srinivasan, and G. Yu. 2014. Securities Litigation Risk for Foreign Companies Listed in the U.S. Working paper, Harvard University.

Chi, W., D. Dhaliwal, O. Z. Li, and T. Lin. 2013. Voluntary reporting incentives and reporting quality: Evidence from a reporting regime change for private firms in Taiwan. Contemporary Accounting Research 30 (4): 1462-1489.

Coffee, J. C., Jr. 1999. The future as history: The prospects for global convergence in corporate governance and its implications. Northwestern University Law Review 93 (3): 641-708.

Coffee, J. C., Jr. 2002. Racing towards the top? The impact of cross-listings and stock market competition on international corporate governance. Columbia Law Review 102 (7): 1757-1831.

Darrough, M. N., R. Huang, and S. Zhao. 2015. The Spillover Effect of Fraud Allegations against Chinese Reverse Mergers. Working paper, Baruch College-CUNY.

Dechow, P. M., and I. D. Dichev. 2002. The quality of accruals and earnings: The role of accrual estimation errors. The Accounting Review 77 (Supplement): 35-59.

Dechow, P. M., R. G. Sloan, and A. P. Sweeney. 1995. Detecting earnings management. The Accounting Review 70 (2): $193-225$.

Dechow, P. M., W. Ge, and C. Schrand. 2010. Understanding earnings quality: A review of the proxies, their determinants and their consequences. Journal of Accounting and Economics 50 (2/3): 344-401.

DeFond, M., and M. Hung. 2004. Investor protection and corporate governance: Evidence from worldwide CEO turnover. Journal of Accounting Research 42: 269-312.

Doidge, C., G. A. Karolyi, and R. M. Stulz. 2004. Why are foreign firms listed in the U.S. worth more? Journal of Financial Economics $71(2):$ 205-238.

Doidge, C., G. A. Karolyi, K. V. Lins, D. P. Miller, and R. M. Stulz. 2009. Private benefits of control, ownership, and the cross-listing decision. Journal of Finance 64 (1): 425-466.

Feldman, D. N. 2009. China: Land of the panda, the Great Wall, and reverse mergers. In Understanding the Securities Laws 2009, Chapter 20. Practising Law Institute Course Handbook. Available at: https://discover.pli.edu/Browse/Title?start= $0 \&$ rows $=10 \& \mathrm{fq}=\sim 2 \mathrm{~B} \sim$ title_id $\sim 3 \mathrm{~A} 282 \mathrm{~B} \sim 18186 \sim 29 \sim \&$ facet $=$ true $\& \mathrm{qt}=$ legal_boolean

Floros, I. V., and K. Shastri. 2009a. A Comparison of Penny Stock Initial Public Offerings and Reverse Mergers as Alternative Mechanisms to Going Public. Working paper, Iowa State University.

Floros, I. V., and K. Shastri. 2009b. An Analysis of Alternate Paths Used by Non-U.S. Firms to List in U.S. Markets: Revisiting the Bonding Hypothesis. Working paper, Iowa State University.

Francis, J., R. LaFond, P. Olsson, and K. Schipper. 2005. The market pricing of accruals quality. Journal of Accounting and Economics 39 (2): 295-327.

Gillis, P. 2011. Understanding Chinese Frauds. Available at: http://chinaaccountingblog.com/weblog/understanding-chinese-fraud.html

Givoly, D., C. Hayn, and B. Lourie. 2014. Importing Accounting Quality? The Case of Foreign Reverse Mergers. Working paper, The Pennsylvania State University.

Gong, G., B. Ke, and Y. Yu. 2013. Home country investor protection, ownership structure and cross-listed firms' compliance with SOXmandated internal control deficiency disclosures. Contemporary Accounting Research 30 (4): 1490-1523.

He, X., T. J. Wong, and D. Young. 2013. U.S. Listing of Chinese Firms: Bonding vs. Adverse Selection. Working paper, The Chinese University of Hong Kong.

Hennes, K. M., A. J. Leone, and B. P. Miller. 2008. The importance of distinguishing errors from irregularities in restatement research: The case of restatements and CEO/CFO turnover. The Accounting Review 83 (6): 1487-1519. 
Hope, O.-K., W. Thomas, and D. Vyas. 2013. Financial reporting quality of U.S. private and public firms. The Accounting Review 88 (5): $1715-1742$.

Hung, M., T. J. Wong, and T. Zhang. 2012. Political considerations in the decision of Chinese SOEs to list in Hong Kong. Journal of Accounting and Economics 53: 435-449.

Jindra, J., T. Voetmann, and R. A. Walkling. 2012. Reverse Mergers: The Chinese Experience. Working paper, The Ohio State University.

Lang, M., J. S. Raedy, and M. H. Yetman. 2003. How representative are firms that are cross-listed in the United States? An analysis of accounting quality. Journal of Accounting Research 41 (2): 363-386.

Lang, M., J. S. Raedy, and W. Wilson. 2006. Earnings management and cross listing: Are reconciled earnings comparable to U.S. earnings? Journal of Accounting and Economics 42 (1/2): 255-283.

Lee, C. M. C., K. K. Li, and R. Zhang. 2015. Shell games: The long-term performance of Chinese reverse-merger firms. The Accounting Review 90 (4): 1547-1589.

Lel, U., and D. P. Miller. 2008. International cross-listing, firm performance, and top management turnover: A test of the bonding hypothesis. Journal of Finance 63 (4): 1897-1937.

Leuz, C. 2006. Cross listing, bonding and firms' reporting incentives: A discussion of Lang, Raedy, and Wilson (2006). Journal of Accounting and Economics 42 (1/2): 285-299.

Leuz, C., D. Nanda, and P. D. Wysocki. 2003. Earnings management and investor protection: An international comparison. Journal of Financial Economics 69 (3): 505-527.

Licht, A. 2003. Cross-listing and corporate governance: Bonding or avoiding? Chicago Journal of International Law 4 (1): 141163.

Licht, A., C. Poliquin, J. I. Siegel, and X. Li. 2013. What Makes the Bonding Stick? A Natural Experiment Involving the U.S. Supreme Court and Cross-Listed Firms. Working paper, Interdisciplinary Center Herzliya, Harvard University, and The Hong Kong University of Science and Technology.

Marosi, A., and N. Massoud. 2008. "You can enter but you cannot leave ...": U.S. securities markets and foreign firms. Journal of Finance 63 (5): 2477-2506.

McMahon, D. 2012. SEC charges China firm with falsifying earnings. Wall Street Journal (September 5). Available at: http://www.wsj. com/articles/SB10000872396390443686004577632783284352236

McNichols, M. F. 2002. Discussion of the quality of accruals and earnings: The role of accrual estimation errors. The Accounting Review 77 (Supplement): 61-69.

McNichols, M. F., and S. R. Stubben. 2008. Does earnings management affect firms' investment decisions? The Accounting Review 83 (6): 1571-1603.

Ndubizu, G. A. 2007. Do cross-border listing firms manage earnings or seize a window of opportunity? The Accounting Review 82 (4): 1009-1030.

Organisation for Economic Co-operation and Development (OECD). 2010. OECD Economic Surveys: China. Available at: http://www. oecd-ilibrary.org/economics/oecd-economic-surveys-china-2010_eco_surveys-chn-2010-en

Pagano, M., A. A. Röell, and J. Zechner. 2002. The geography of equity listing: Why do companies list abroad? Journal of Finance 57 (6): 2651-2694.

Public Company Accounting Oversight Board (PCAOB). 2011. Activity Summary and Audit Implications for Reverse Mergers Involving Companies from the China Region: January 1, 2007 through March 31, 2010. Research Note 2011-P1. (March 14). Available at: http://pcaobus.org/research/documents/chinese_reverse_merger_research_note.pdf

Securities and Exchange Commission (SEC). 2011. Investor Bulletin: Reverse Mergers. Available at: https://www.sec.gov/investor/alerts/ reversemergers.pdf

Securities and Exchange Commission (SEC). 2012. Investor Bulletin: American Depositary Receipts. Available at: https://www.sec.gov/ investor/alerts/adr-bulletin.pdf

Shleifer, A., and R. W. Vishny. 1997. A survey of corporate governance. Journal of Finance 52 (2): 737-783.

Siegel, J. 2005. Can foreign firms bond themselves effectively by renting U.S. securities laws? Journal of Financial Economics 75 (2): 319-359.

Siegel, J., and Y. Wang. 2013. Cross-Border Reverse Mergers: Causes and Consequences. Working paper, Harvard University.

Srinivasan, S., A. S. Wahid, and G. Yu. 2015. Admitting mistakes: Home country effect on the reliability of restatement reporting. The Accounting Review 90 (3): 1201-1240.

Stubben, S. R. 2010. Discretionary revenues as a measure of earnings management. The Accounting Review 85 (2): $695-717$.

Stulz, R. M. 1999. Globalization, corporate finance, and the cost of capital. Journal of Applied Corporate Finance 12 (3): 8-25.

Templin, B. A. 2012. Chinese reverse mergers, accounting regimes, and the rule of law in China. Thomas Jefferson Law Review 34 (1): 101-151.

Teoh, S. H., I. Welch, and T. J. Wong. 1998. Earnings management and the underperformance of seasoned equity offerings. Journal of Financial Economics 50 (1): 63-99.

Wilson, W. 2008. An empirical analysis of the decline in the information content of earnings following restatements. The Accounting Review 83 (2): 519-548. 


\section{APPENDIX A}

\section{Measurement of Individual Accrual-Based Financial Reporting Quality Variables}

This appendix describes the detailed measurement of the four individual accrual-based financial reporting quality measures used in this study.

Our first measure is the absolute value of discretionary accruals. Discretionary accruals are estimated from the modified Jones model, as in Dechow et al. (1995). Specifically, we estimate the following regression model:

$$
A C C R_{i, t}=\alpha_{1}\left(\frac{1}{T A_{i, t}}\right)+\alpha_{2}\left(\Delta R E V_{i, t}-\triangle R E C_{i, t}\right)+\alpha_{3} P P E_{i, t}+\varepsilon_{i, t},
$$

where $A C C R$ is total accruals, calculated as the difference between income before extraordinary items and operating cash flows; $T A$ is total assets at the beginning of the year; $\triangle R E V$ is the change in sales; $\triangle R E C$ is the change in accounts receivable; and $P P E$ is gross property, plant, and equipment. In the above equation, all of the variables are scaled by $T A$. The above regression model is estimated by industry-year using all firm-year observations (industries being defined based on two-digit SIC codes). The regression residual is discretionary accruals $(D A)$. We use the absolute value of $D A(|D A|)$ as our first measure of financial reporting quality.

Our second measure is based on a modified version of the cross-sectional Dechow and Dichev (2002) model. The Dechow and Dichev (2002) model focuses on the strength of the relation between current accruals and past, present, and future cash flows. In particular, we use the Dechow and Dichev (2002) model as modified by McNichols (2002) and Francis et al. (2005), adjusting for negative cash flows (Ball and Shivakumar 2006). Specifically, we estimate the following model for each industryyear that has at least 20 observations:

$$
W C A_{i, t}=\alpha_{0}+\beta_{1} O C F_{i, t-1}+\beta_{2} O C F_{i, t}+\beta_{3} O C F_{i, t+1}+\beta_{4} \Delta R E V_{i, t}+\beta_{5} P P E_{i, t}+\beta_{6} D O C F_{i, t}+\beta_{7} O C F_{i, t} \times D O C F_{i, t}+\varepsilon_{i, t},
$$

where $W C A$ is working capital accruals, measured as the change in non-cash current assets minus the change in current liabilities (other than short-term debt and taxes payable), scaled by lagged total assets; $O C F$ is operating cash flows, measured as the sum of net income, depreciation, and amortization, minus $W C A$, scaled by lagged total assets; $\triangle R E V$ and $P P E$ are defined as above; and $D O C F$ is an indicator variable for negative operating cash flows. The residual from the above equation represents the component in the current accruals that is not associated with operating cash flows and that cannot be explained by the change in revenue or the level of PPE. We use the absolute value of this residual $(|D D|)$ as a proxy for financial reporting quality.

Our third measure is the absolute value of discretionary revenues based on McNichols and Stubben (2008) and Stubben (2010). Specifically, we estimate the following regression for each industry-year that has at least 20 observations:

$$
\Delta A R_{i, t}=\alpha_{0}+\beta_{1} \Delta R E V_{i, t}+\varepsilon_{i, t}
$$

where $\triangle A R$ represents the annual change in accounts receivable scaled by lagged total assets; and $\triangle R E V$ is as defined above. Discretionary revenue $(D R)$ is the residual from this regression, and its absolute value, $|D R|$, is used as a proxy for financial reporting quality.

Our fourth measure is based on the ratio of the absolute value of accruals to cash flows (Burgstahler et al. 2006; Hope et al. 2013). Firms may overstate earnings to achieve certain targets or to report good performance in specific instances, such as equity issuance (Teoh, Welch, and Wong 1998). Similarly, in years with poor performance, firms may boost their earnings using reserves or engage in aggressive accounting practices. Earnings can be temporarily inflated due to accrual choices, but cash flows remain unaffected. In such cases, the higher the ratio, the lower the financial reporting quality. To avoid the effect of extreme values, we use the $\log$ transformation of this ratio, $\ln |A C C R / O C F|$, as our fourth proxy. 


\section{APPENDIX B \\ Variable Definitions}

Variable

Dependent Variables

Restatement

Error

Irregularity

$|D A|$

$|D D|$

$|D R|$

$\ln |A C C R / O C F|$

$F R Q$

Independent Variables

$R M$

China

CRM

$M / B$

Growth

$L E V$

$R O E$

Size

Capital_Need

Loss

Op_Cycle

Inventory
Definition

Restatement dummy equal to 1 if the financial statement of the firm in that year is restated later, and 0 otherwise; Indicator variable for accounting errors, equal to 1 if the financial statement of the firm in that year is restated later and the restatement is classified as an error, and 0 otherwise;

Indicator variable for accounting irregularities; equal to 1 if the financial statement of the firm in that year is restated later and the restatement is classified as an accounting irregularity, and 0 otherwise;

Absolute value of discretionary accruals, as described in Appendix A;

Absolute value of discretionary working capital accruals, as described in Appendix A;

Absolute value of discretionary revenue, as described in Appendix A;

The natural logarithm of the ratio of the absolute value of total accruals to operating cash flows, as described in Appendix A; and

The financial reporting quality index, measured as the common factor from the principal component analysis of the four individual measures $|D A|,|D D|,|D R|$, and $\ln |A C C R / O C F|$.

RM firm dummy equal to 1 if the firm is an RM firm, and 0 otherwise;

Chinese firm dummy equal to 1 if the firm is a Chinese firm, and 0 otherwise;

Chinese RM firm dummy equal to 1 if the firm is a Chinese RM firm, and 0 otherwise;

The market-to-book ratio, calculated as market value of equity divided by book value of equity;

Sales growth, measured as the percentage change in sales;

The leverage ratio, measured as total debt divided by total assets;

Return on equity, measured as income before extraordinary items divided by shareholders' equity;

Firm size, measured as the natural logarithm of total assets;

The percentage change in common stock, preferred stock, and long-term debt in the following year;

The cumulative percentage of sample years that the firm reported a loss during the sample period;

Operating cycle of the firm, measured as Inventory/Cost of Sales + Receivables/Sales; and

Inventory divided by total assets. 